Annual Technical Report

on

\title{
Dimethyl Ether (DME)-Fueled Shuttle Bus Demonstration Project
}

\author{
For the Period \\ July 1, 2001 - June 30, 2002
}

by

Elana M. Chapman, Shirish Bhide, Jennifer Stefanik, Howard Glunt, André L. Boehman, Allen Homan

and

David Klinikowski

Revised Report Submitted April, 2003

Contract No. DE-FG26-99FT40161

Submitting Organization

The Energy Institute

The Pennsylvania Transportation Institute

The Pennsylvania State University

University Park, PA 16802 


\section{DISCLAIMER}

This report was prepared as an account of work sponsored by an agency of the United States Government. Neither the United States Government nor any agency thereof, nor any of their employees, makes any warranty, express or implied, or assumes any legal liability or responsibility for the accuracy, completeness, or usefulness of any information, apparatus, product, or process disclosed, or represents that its use would not infringe privately owned rights. Reference herein to any specific commercial product, process, or service by trade name, trademark, manufacturer, or otherwise does not necessarily constitute or imply its endorsement, recommendation, or favoring by the United States Government or any agency thereof. The views and opinions of authors expressed herein do not necessarily state or reflect those of the United States Government or any agency thereof. 


\begin{abstract}
The objectives of this research and demonstration program are to convert a campus shuttle bus to operation on dimethyl ether, a potential ultra-clean alternative diesel fuel. To accomplish this objective, this project includes laboratory evaluation of a fuel conversion strategy, as well as, field demonstration of the DME-fueled shuttle bus. Since DME is a fuel with no lubricity (i.e., it does not possess the lubricating quality of diesel fuel), conventional fuel delivery and fuel injection systems are not compatible with dimethyl ether. Therefore, to operate a diesel engine on DME one must develop a fuel-tolerant injection system, or find a way to provide the necessary lubricity to the DME. In this project, we have chosen the latter strategy in order to achieve the objective with minimal need to modify the engine. Our strategy is to blend DME with diesel fuel, to obtain the necessary lubricity to protect the fuel injection system and to achieve low emissions. The bulk of our efforts over the past year were focused on the conversion of the campus shuttle bus. This process, started in August 2001, took until April 2002 to complete. The process culminated in an "event" to celebrate the launching of the shuttle bus on DME-diesel operation on April 19,2002. The design of the system on the shuttle bus was patterned after the system developed in the engine laboratory, but also was subjected to a rigorous failure modes effects analysis (FMEA, referred to by Air Products as a "HAZOP" analysis) with help from Dr. James Hansel of Air Products. The result of this FMEA was the addition of layers of redundancy and over-pressure protection to the system on the shuttle bus. The system became operational in February 2002. Preliminary emissions tests and basic operation of the shuttle bus took place at the Pennsylvania Transportation Institute's test track facility near the University Park airport. After modification and optimization of the system on the bus, operation on the campus shuttle route began in early June 2002. However, the work and challenges have continued as it has been difficult to maintain operability of the shuttle bus due to fuel and component difficulties. As of late June 2002, it appears that the pump head itself developed operational problems (loss of smooth function) leading to excessive stress on the magnetic coupling and excessive current draw to operate. A new pump head is being installed on the system to alleviate this problems and get the shuttle bus back in operation. In summary, the conversion is completed but there have been operational challenges in the field. We continue to work to make the shuttle bus as reliable to operate on DME-diesel blends as possible.
\end{abstract}




\section{TABLE OF CONTENTS}

Disclaimer .............................................................................. ii

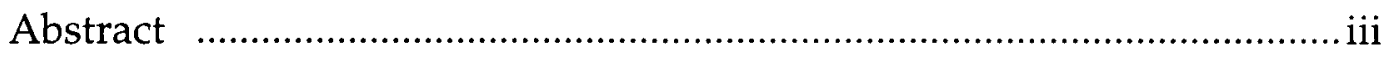

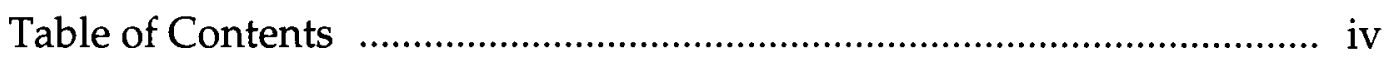

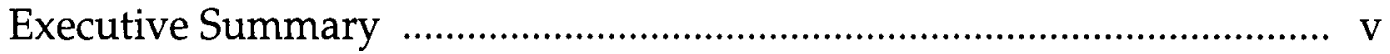

Experimental ............................................................................ 1

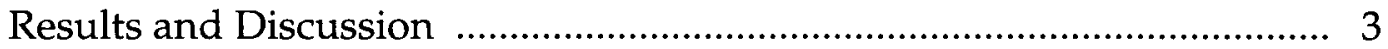

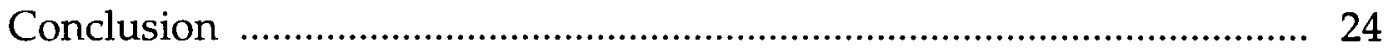

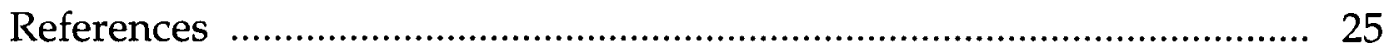

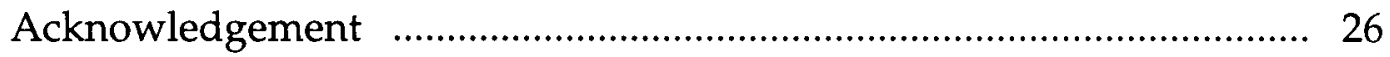

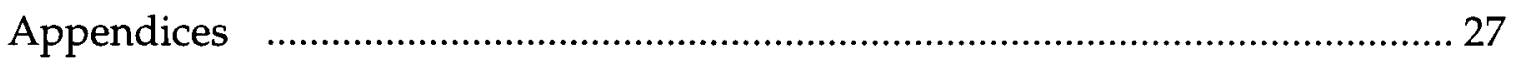

ACS Preprint from 2001 ACS National Meeting ............................... 28

Society of Automotive Engineers Technical Paper No. 2001-01-3626 ... 30 


\section{EXECUTIVE SUMMARY}

The objectives of this research and demonstration program are to convert a campus shuttle bus to operation on dimethyl ether, a potential ultra-clean alternative diesel fuel. To accomplish this objective, this project includes laboratory evaluation of a fuel conversion strategy, as well as, field demonstration of the DME-fueled shuttle bus. Since DME is a fuel with no lubricity (i.e., it does not possess the lubricating quality of diesel fuel), conventional fuel delivery and fuel injection systems are not compatible with dimethyl ether. Therefore, to operate a diesel engine on DME one must develop a fuel-tolerant injection system, or find a way to provide the necessary lubricity to the DME. In this project, we have chosen the latter strategy in order to achieve the objective with minimal need to modify the engine. Our strategy is to blend DME with diesel fuel, to obtain the necessary lubricity to protect the fuel injection system and to achieve low emissions. Sponsorship comes from the National Energy Technology Laboratory (Project Manager Jenny Tennant, and Program Manager John Winslow), the Pennsylvania Department of Environmental Protection Alternative Fuel Incentive Grant Program (Program Manager Susan Summers) and Air Products and Chemicals, Inc. (Program Manager Ed Heydorn).

To date, our activities have covered two areas: laboratory investigations and field investigations. The laboratory studies have included work with a Navistar V-8 turbodiesel engine, demonstration of engine operation on DME-diesel blends and instrumentation for evaluating fuel properties. The field studies have involved performance, efficiency and emissions measurements with the Champion Motorcoach "Defender" shuttle bus and conversion of the shuttle bus operation on DME-diesel blends.

Within the Diesel Combustion and Emissions Laboratory in the Penn State Energy Institute, we have installed and equipped a Navistar V-8 direct-injection turbodiesel engine for measurement of gaseous and particulate emissions and examination of the impact of fuel composition on diesel combustion. We have also reconfigured a high-pressure viscometer for studies of the viscosity, bulk modulus (compressibility) and miscibility of blends of diesel fuel, dimethyl ether and lubricity additives. Our results include baseline emissions, performance and combustion measurements on the Navistar engine for operation on a federal low sulfur diesel fuel (300 ppm S). In the past year, we completed analysis of test results for DME-diesel blends up to 30 vol.\% (25 wt.\%) DME. The results included detailed analysis of cylinder pressure trace data, injection parameters reported by the ECM on the engine and emissions data. The results were partly summarized in a Society of Automotive Engineers paper and were summarized in detail in the MS Thesis of Elana Chapman.

We have also performed viscosity measurements on diesel fuel, DME and blends of DME in diesel. These tests have verified that DME has a much lower viscosity than the diesel fuel and that the viscosity of the blended fuel is also much lower than the diesel base fuel. This has implications for the injection and atomization of the DME/diesel blends. The test results on fuel viscosity were summarized in an ACS Preprint presented at the 2001 ACS National Meeting in Chicago.

The bulk of our efforts over the past year were focused on the conversion of the campus shuttle bus. This process, started in August 2001, took until April 2002 to complete. The process 
culminated in an "event" to celebrate the launching of the shuttle bus on DME-diesel operation on April 19, 2002. The design of the system on the shuttle bus was patterned after the system developed in the engine laboratory, but also was subjected to a rigorous failure modes effects analysis (FMEA, referred to by Air Products as a "HAZOP" analysis) with help from Dr. James Hansel of Air Products. The result of this FMEA was the addition of layers of redundancy and over-pressure protection to the system on the shuttle bus. The system became operational in February 2002. Preliminary emissions tests and basic operation of the shuttle bus took place at the Pennsylvania Transportation Institute's test track facility near the University Park airport.

After another month's worth of modification and optimization of the system on the bus, operation on the campus shuttle route began in early June 2002. However, the work and challenges have continued as it has been difficult to maintain operability of the shuttle bus due to fuel and component difficulties. The difficulties with the converted fuel system have arisen in two areas: operation of the converted fueling system, which circulates fuel to the engine; and operation of the engine, which has run very rough at times and is emitting a significant amount of "blow by" that indicates the engine may need an overhaul.

The difficulties with the fuel circulation system have been primarily with the gear pump which draws DME-diesel fuel blend from the onboard mixture tank. The pump developed operational problems that appeared to either be cavitation (possible if DME vaporized in our fueling system) or loss of magnetic coupling between the pump head and electric motor. The latter turns out to be the main problem, although this magnetic coupling has been replaced on the vehicle once already. As of late June 2002, it appears that the pump head itself developed operational problems (loss of smooth function) leading to excessive stress on the magnetic coupling and excessive current draw to operate. A new pump head is being installed on the system to alleviate this problems and get the shuttle bus back in operation.

In summary, the conversion is completed but there have been operational challenges in the field. We continue to work to make the shuttle bus as reliable to operate on DME-diesel blends as possible. 


\section{EXPERIMENTAL}

This project is driven by Air Products' interest in the development of markets for the Liquid Phase Dimethyl Ether process technology, the state's interest in development of transportation fuel usage from Pennsylvania resources (e.g., coal) and the Department of Energy's interest in ultra-clean transportation fuels. In this project we (Penn State Energy Institute and Air Products and Chemicals, Inc.) have determined how to effect the conversion of a shuttle bus equipped with a Navistar DI turbo-diesel engine to operation on Dimethyl Ether (DME). To accomplish this goal, we have been examining the co-firing of the engine on diesel fuel and dimethyl ether, using the diesel fuel as a lubricating agent to protect the fuel pump and fuel injection system from excessive wear. Dimethyl ether has no natural lubricity, making it antagonistic to fuel system components.

The work consists of two parallel efforts. One is an evaluation of the performance, emissions and efficiency of a shuttle bus equipped with a diesel engine and operated on dimethyl ether. That work is relying on the bus testing facilities and portable emissions analysis equipment of the Pennsylvania Transportation Institute (PTI). The other is the development of a conversion process to operate a diesel engine on dimethyl ether using conventional fuel injection equipment. PTI is evaluating the in-service performance, emissions and efficiency of the shuttle bus (Champion "Defender" model) that serves as a faculty/staff shuttle on the University Park campus. Initially, the bus is being operated on diesel fuel to provide baseline information. Tests have been performed since break-in of the vehicle and will be performed at several intervals after the conversion to dimethyl ether operation.

Meanwhile, we have been working on the development of a conversion strategy to operate a Navistar T444E turbodiesel engine, identical to the one in the shuttle bus, to operation on blends of DME and diesel. We have demonstrated that the laboratory engine can be operated effectively on the blended fuel.

At the same time, we have designed a large scale, dedicated DME fueling station for delivery of DME-diesel blends. The cost of the initial design, however, was well beyond the level of funding available for the fueling station. Instead, we have developed a simpler plan that involves a two-stage fueling process. The driver of the shuttle bus will use the existing diesel fuel pumps for University service vehicles to fill the bus' main tank with diesel fuel. This diesel fuel will be transferred to the DME-diesel mixture tank. Then, the driver will back up to an adjacent storage location for the DME tank to add the DME to the shuttle bus.

The objectives of the laboratory testing have been to determine the compositions of fuel and additive blends that will permit long term operation of the T444E engine on dimethyl ether. We have successfully operated the laboratory engine on blends with up to $30 \mathrm{wt} . \% \mathrm{DME}$. Based on these tests, we have determined that the optimal blend ratio for the field vehicle is $25 \mathrm{wt} \% \mathrm{DME}$ in diesel fuel.

Through collaboration with the Tribology Laboratory in Penn State's Chemical Engineering Department, we are characterizing the viscosity, compressibility and miscibility of blends of DME, diesel fuel and the additives under pressures and temperatures relevant to the fuel 
injection system. These tests are using a high pressure viscometer adapted to these specific experiments. In addition under a new project with support from NETL, we will construct an injector durability experiment to determine the time to failure and boundary of the of fuel composition which can lead to injector failure. Also, we will modify an existing pin-on-ring apparatus to investigate the lubricity of DME blends with diesel fuel and lubricity additives.

At present, we are selecting and designing fuel system hardware for use on the shuttle bus to convert it to DME-diesel operation. The conversion is now planned to occur during May and June of 2001. Then PTI will perform the emissions, performance and efficiency tests on the converted vehicle at several intervals over an 18-month period. The diesel engine in the laboratory will continue to be operated on DME for continuing studies of fuel system durability and optimization.

Several companies have been willing to participate in this project. Navistar International has contributed funds to purchase the laboratory engine, provided technical guidance during the laboratory studies, and a cost share on the shuttle bus. Champion Motorcoach provided a cost share on the purchase of the shuttle bus. Lubrizol and Ethyl Additives have provided samples of lubricity agents. Caterpillar (manufacturer of the HEUI fuel injectors on the Navistar T444E turbodiesel engine) has agreed to participate in a new, related project on injector durability which will lead to more DME tolerant fuel injector design. Dupont Fluorocarbons have provided over $500 \mathrm{lbs}$ of DME for use in the engine studies. We are presently negotiating with DuPont Fluorocarbons regarding their providing DME at a discounted price for the field vehicle demonstration.

The most significant technical challenge in this project is accounting for the lubricating quality of the fuel and additive mixtures. This involves two considerations of the mixtures: (1) the lubricating quality of the mixtures; and (2) the phase behavior of the mixtures, given that advanced diesel fuel injection systems use injection pressures that exceed the critical pressure of DME. At higher DME blend ratios, we have observed some instability in the laboratory engine, perhaps due to generation of excessive amounts of DME vapor. This is one aspect of engine operation on DME-diesel blends that we will need to monitor closely during the field evaluation.

The rest of this report consists of a section for each of the major activities (tasks) under the project.

- Laboratory Engine Results

- Viscometer Results

- Fuel Station Construction and Shuttle Bus Conversion 


\section{RESULTS AND DISCUSSION}

\section{Laboratory Engine Results}

The laboratory engine, a Navistar T444E 190hp V-8 Turbodiesel has been operational since October 1999 in our engine test cell. The engine is outfitted with numerous thermocouple sensors, an in-cylinder pressure sensor (in Cylinder \#1) and the exhaust system has a number of ports for sampling particulate emissions, gaseous emissions (including total hydrocarbons) and particulate composition (via thermal analysis). The figure below shows a digital photo of the engine in the test cell prior to the fuel system conversion.

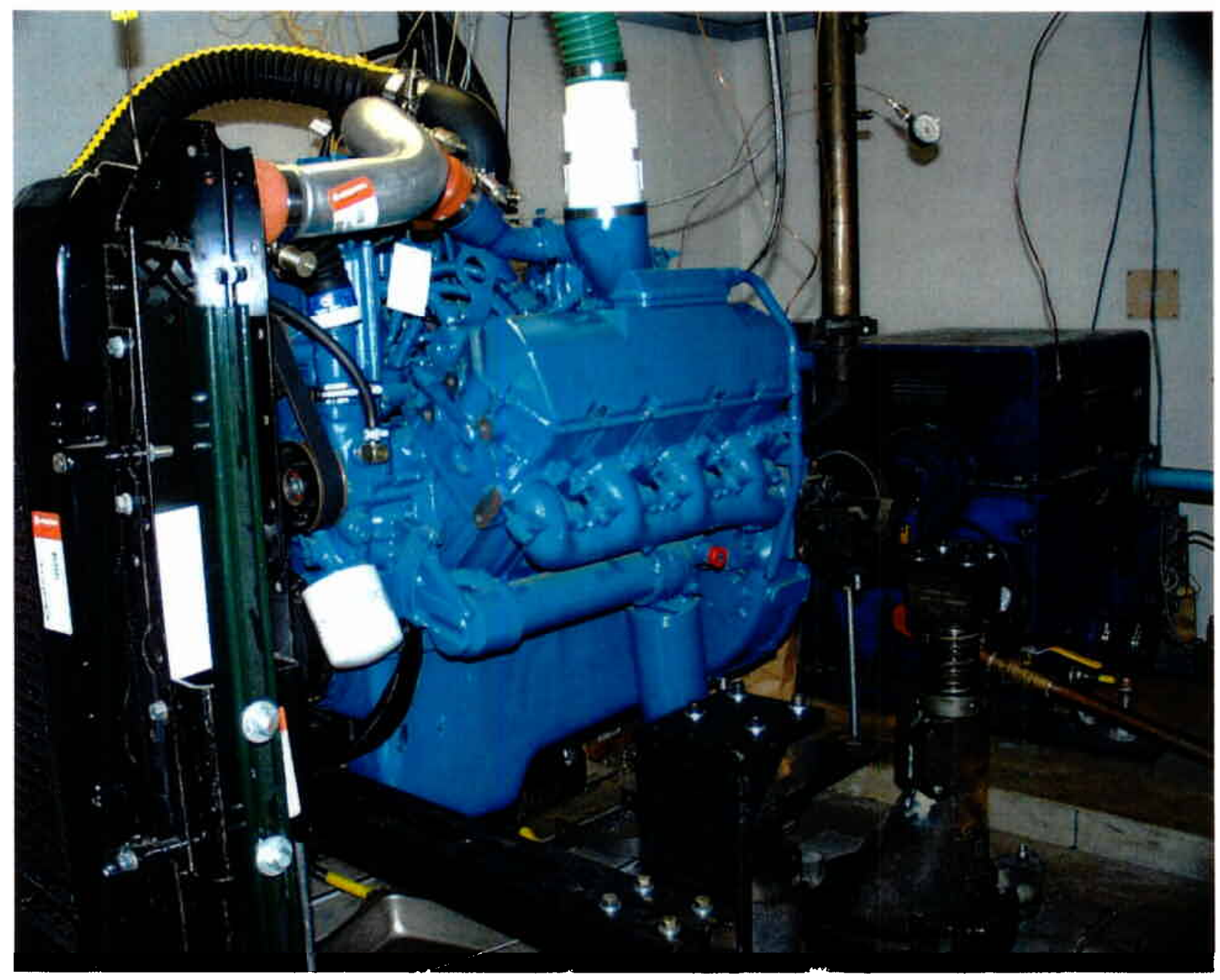

Figure 1. Photo of the Navistar T444E Turbodiesel Engine in the 450 hp Engine Test Cell Prior to Conversion to DME-Diesel Blends

The AVL steady state 8 mode test had been selected to do the emissions comparison studies for different fuel additives and blend ratios of DME to diesel. During previous tests, a comparison of 
exhaust emissions was made with two different oxygenates, the CETANER ${ }^{\mathrm{TM}}$ fuel additive and Dimethyl ether (DME). These were blended with a federal low sulfur diesel fuel that will also serve as the baseline fuel. The oxygenates were blended such that the oxygen content of the mixture was 2\% by mass (reported in SAE Technical Paper NO. 2000-01-2887. More recently, tests were completed at 5 and $10 \mathrm{wt} \%$ oxygen addition by blending DME and diesel fuel, which is equivalent to 15 vol.\% (12.5 wt.\%) and 30 vol.\% (25 wt.\%) DME addition, respectively. The Appendix includes a copy of a Society of Automotive Engineers technical paper that was written on the results from the DME-diesel blend studies.

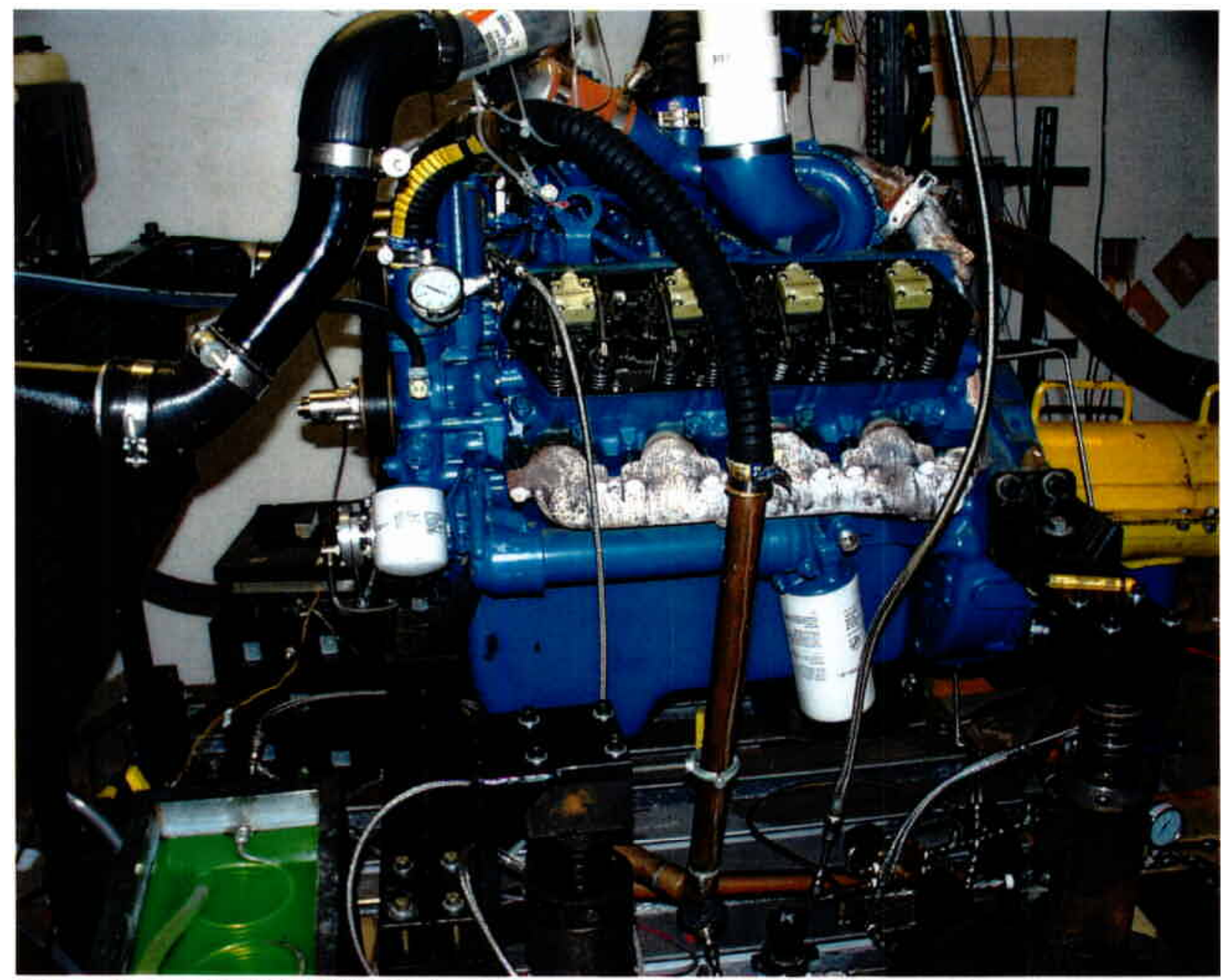

Figure 2. Navistar T444E showing conversion to DME-diesel operation.

\section{Emissions Evaluation- Low DME/Diesel Concentration Tests}

As of March 2002, engine tests had been completed with conservative blends of Dimethyl Ether (DME) blended in diesel fuel. The data was reduced and analyzed during summer and fall 2001. The purpose of the data collection was to determine the effect of the fuel blends on emissions. As with most all oxygenated fuel blends, there was a particulate reduction observed as the oxygen concentration was increased, and for most all of the 8 modes tested (variations of speed and load). However, the other emissions showed scattered results across the modes. This data 
was prepared and presented in two papers during the last year [1, 2], which are attached in this report.

As the engine load was increased and regardless of engine speed, the particulate emission was lowered, except for mode 7. To further understand the variations in the emissions data, the data from the engine electronics was reviewed. Of specific interest was the actions of the fuel injectors, as shown in Figures 3,4 and 5, since the electronic controls of the engine had not been changed from the production calibration, yet the fuel density was different.

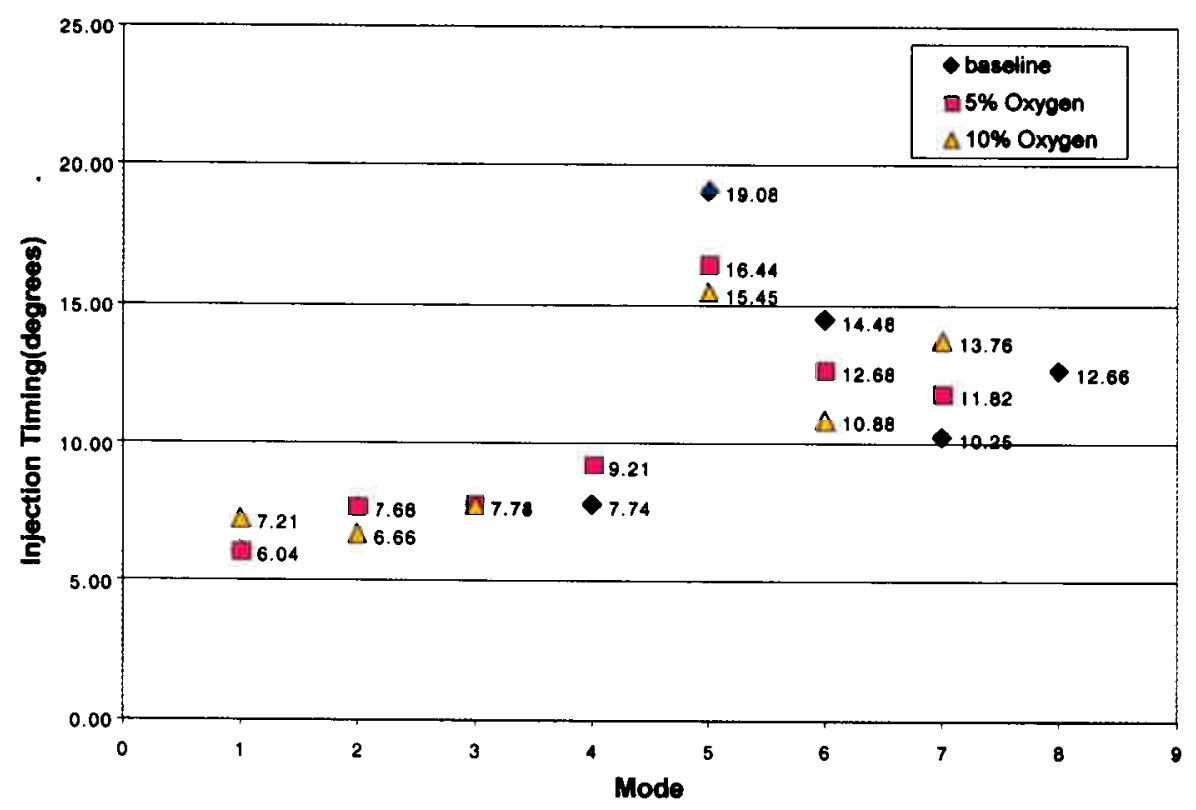

Figure 3. Engine Injection Timing

(* Injection timing is relative to the number of degrees before 0 degrees: TDC (Top Dead Center)) 


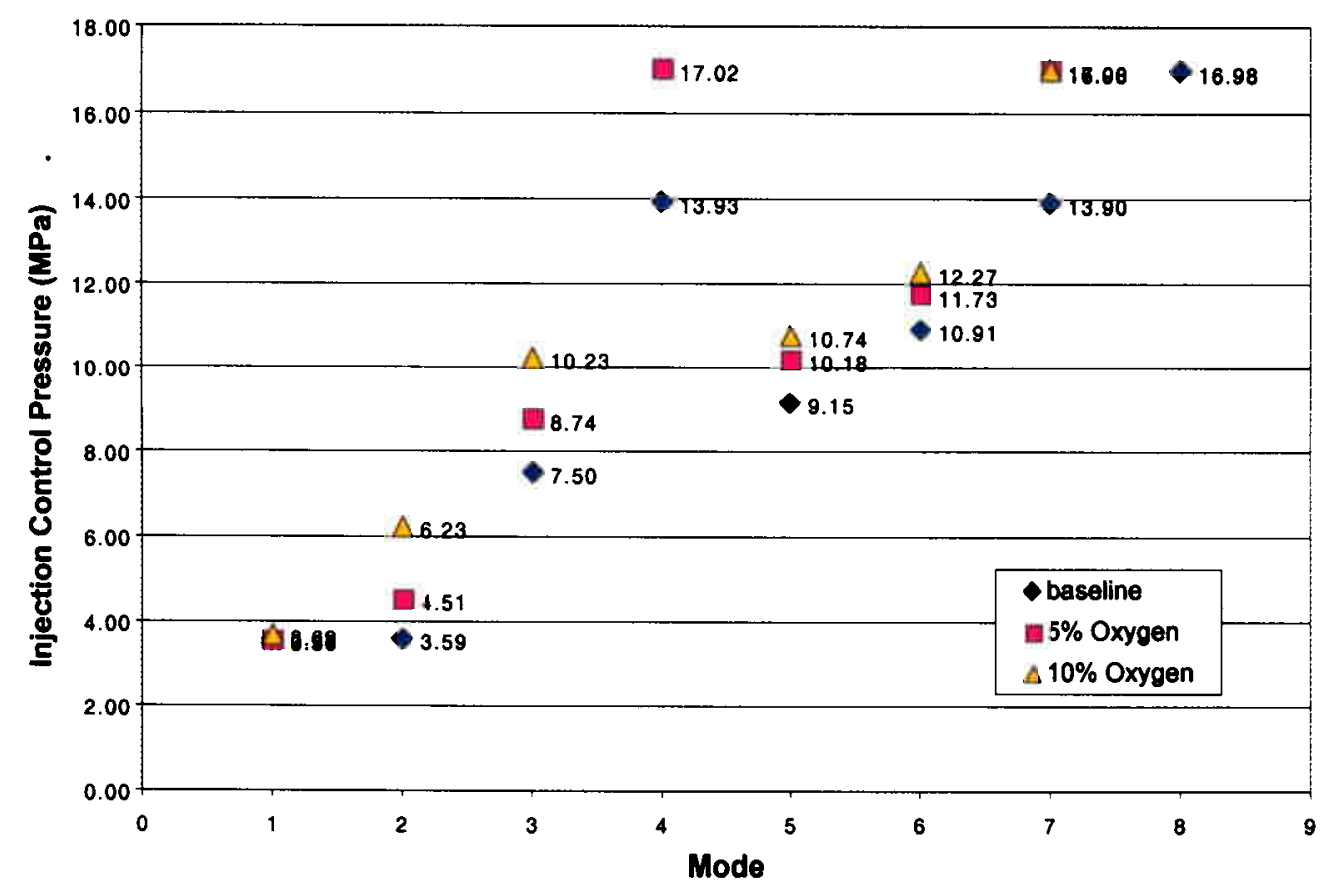

Figure 4. Engine Injection Pressure

The effect seen in Mode 7 may be due to a change in the injection timing. As shown in Figure 3 and Figure 4, the injection timing and injection pressure were changing as commanded by the engine control for changing speed and load. This is true for the low as well as the high engine speeds. The trends follow what would be expected based on the work by Kajitani and coworkers [3]. Their work showed that as the mean effective pressure increases, which correlates with increasing load, for an engine speed of $960 \mathrm{RPM}$, so does soot emissions based on the Bosch Smoke Number with diesel fuel. In their work, the DME emissions were close to zero. In this work, with increasing content of DME, the soot emissions decrease.

As has been shown in previous work by Liotta and co-workers, this particulate reduction is due to a reduction in the soot portion of the emission, and would result in a percentage increase in the soluble organic faction (SOF) portion [4]. This has also been confirmed more recently by Sidhu and coworkers [5], with DME giving the highest SOF.

As can be seen in Figure 3, the injection timing of the engine was changing so as to increase the amount of fuel to meet the speed and load condition. Mode 3 was the only mode where the injection timing did not change, and shows that the $\mathrm{NO}_{\mathrm{x}}$ does increase with DME addition. However, injection pressure was increasing so that the required fuel energy could be injected into the cylinder over the same crank angle timing. This may explain the increase in $\mathrm{NO}_{\mathbf{x}}$. 
Because of DME's vapor pressure, as the fuel is injected into the engine, the DME may be acting to atomize the diesel fuel into a finer spray. The blended fuel has a lower density than the diesel fuel, and the compressibility of the fuel blend has also changed. This may be reducing the premixed phase of combustion, causing more of the combustion process to be diffusioncontrolled because the fuel is vaporizing and igniting so quickly. Additionally, more fuel by volume is being injected to maintain the same energy density and thus the same speed and load conditions. So, there could be some small increase in $\mathrm{NO}_{\mathrm{x}}$ emissions for this reason. In Figure 6, the brake specific energy consumption shows that the same amount of fuel on an energy basis is used for each mode, except for mode 1 . Since the fuel is less dense and has higher compressibility, this may be affecting the fuel leaving the injector port and modifying the air entrainment into the fuel jet. Kajitani and coworkers data supports the increase in $\mathrm{NO}_{\mathbf{x}}$ emissions [3].

As described before, the engine was commanding more fuel, which caused the fuel injection pressure, as well as, the fuel injection timing to shift. The fuel volume required is also confirmed by the engine control signals, shown in Figure 5. From a fuel consumption standpoint, as DME content increased the volume of fuel being commanded from the engine control increased, but reached the maximum limit. This could be the result of the maximum limit, the fuel injection pressure limit and possibly the injection timing limit, within the engine control program. 


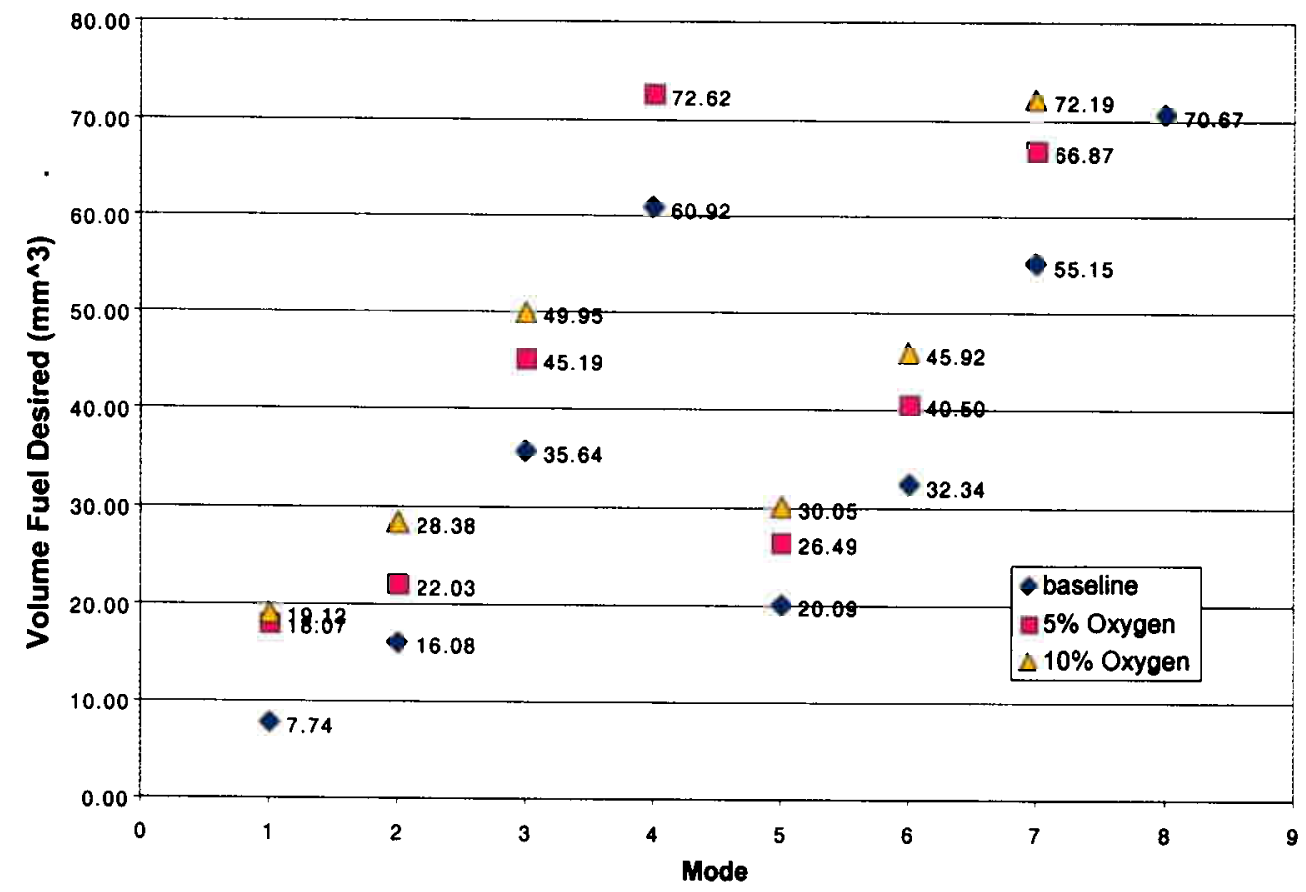

Figure 5. Engine control commanded fuel volume desired

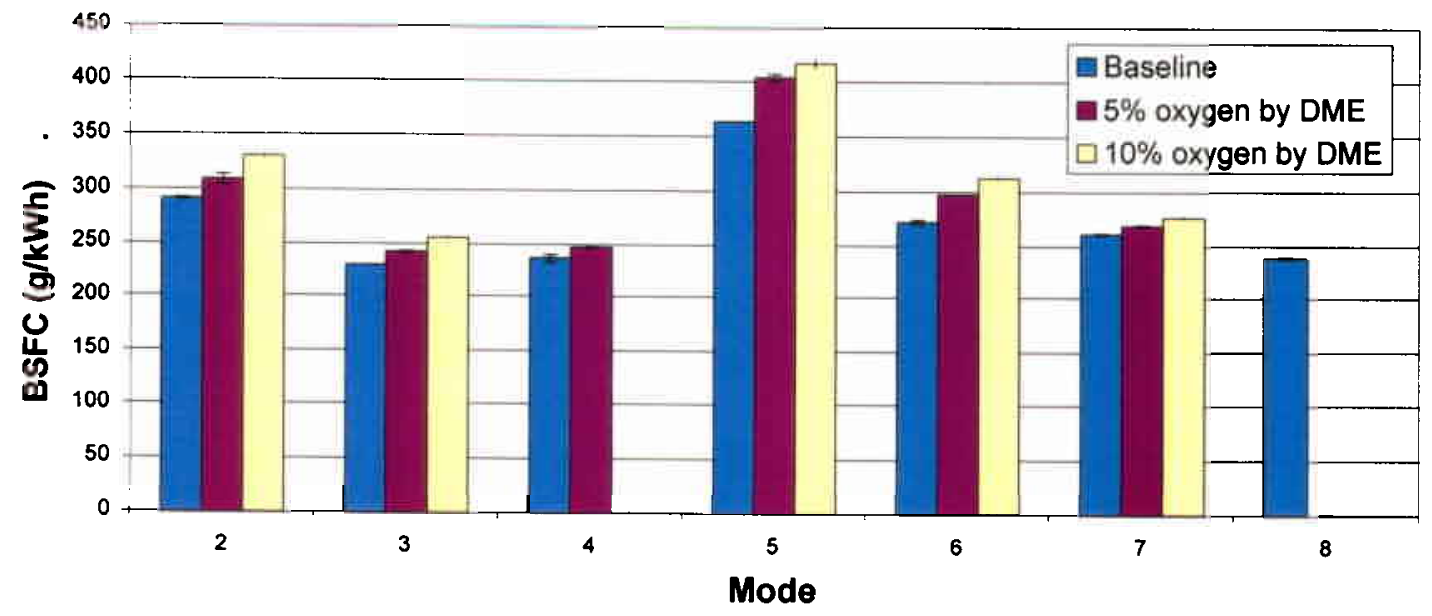

Figure 6. Fuel Consumption 


\section{Laboratory Engine Operational Challenges}

During the data analysis phase, the engine was operated occasionally to prepare the fuel system for the Bus Project. There were several issues to address, with the major one being the gear swell of the fuel pump.

After discussion with the pump manufacturer (Tuthill) that was chosen, a compromise design was concluded to be the best approach based on the pressure, temperature, and flow rate envelope of the fuel system. Since the swell rate of the gears was not known, and the bus fuel systems would be designed to leave the fuel on the fuel system upon shutdown, it was critical to find a solution. In the engine lab, experience was gained with gear swell from DME/diesel blends. The initial material selection was PPS (Polyphenylene Sulfide, Carbon Fiber reinforced), which was believed to be the best with regard to the materials the manufacturer could offer. So, to accommodate the pump for the situation with the bus, it was decided to increase the tolerance in the gears so that the pump would not shut down after immersion in the fuel over an extended period of time. By doing this, the flow rate from the pump was reduced. It should be noted that the ability of the pressurized fuel system to keep the fuel in a liquid form is a function of pressure, temperature, and flow rate.

Additionally, when preparing the engine to test the modified fuel pump, starting problems were encountered. It was initially thought that this failure was due to possible early wear in the injectors. After installing and using the electronics which govern the glow plug, to ensure that the cylinder was adequately heated before the engine was started, this was not found to correct the issue. Further work determined that the electrical system of the engine is sensitive to battery voltage. After placing a deep charge on the battery, the engine started without any problems. This was a significant step, in that after not operating the engine for several months, engine wear due to the fuel blends had not been the cause of the failure, and did not present concern for the bus project.

\section{Laboratory Engine Evaluation for Bus Project Fuel System Design}

Based on the finalized Failure Modes and Effects Analysis (FMEA) of the bus fuel system design, a number of engine tests were proposed to validate the robustness of the system. These tests included the following:

1. Repeatedly start the engine to confirm the starting problem has been corrected.

2. Test Bus Heat exchangers to confirm that the thermal capacity on the steady state lab engine test is greater than what the bus would experience. Use a thermal couple in the system to determine the time it takes for the system to heat up and stabilized.

3. Test flammable gas monitors

4. Perform Injector test with electronic service tool

5. Test Evaporative canisters for system vapor on shutdown. 
As the bus system development and testing moved forward, decisions were made to go without the Evaporative Canister system, as a vapor test on the bus system proved this was not an issue. Also, engine lab evaluations on the heat exchangers showed that the initial system was undersized and greater exchange capability was need, including the addition of a fan. Finally, as the bus system developed and failures were experienced, the lab engine was used to test out theories of operation, in order to demonstrate a failure mode and provide corrective action for the bus system. It proved to be a valuable tool for this purpose.

At this time, utilizing the service tool to test the injectors was not possible due to several of the external components of the engine electronics not being available. The service tool performs a series of system checks before testing the injectors, and the electronic inputs necessary were not able to be "stepped" through in the service tool software. This test will be valuable to perform in the future injector study, so some time will be spent in determining the necessary inputs and software safety stops, so that it can be used as a diagnostic approach in the injector studies. 
Viscometer Progress Report.

\section{High Pressure Viscometer Setup}

To optimize the performance of a fuel injection system for a particular fuel or fuel blend, it is very important to have a good estimate of the physical properties of those fuels. It is equally important to know the change in properties with change in pressure and temperature. An experiment was configured to measure the viscosity of diesel, DME and their blends at various pressures. The high pressure viscometer apparatus used for this work was designed and built at The Pennsylvania State University in 1962-63. This apparatus was modified to allow for charging of a pressurized liquid sample, as is necessary when dealing with compressed liquids. Robert Johnson in his Master's thesis, gives a detailed description of the design and use of the apparatus. The thesis presents an excellent overview and a summary of the work done in the field of high pressure viscometry up to 1962 . The equipment very simple in design, is nevertheless extremely accurate in viscosity measurement up to a pressure of 10,000 psig.

\section{Description of High Pressure Viscometer}

A schematic diagram of the apparatus setup is shown in Figure 7. The setup consists of a pressure intensifying system, a pressure measurement system, a constant temperature bath and the viscometer pressure vessel. 


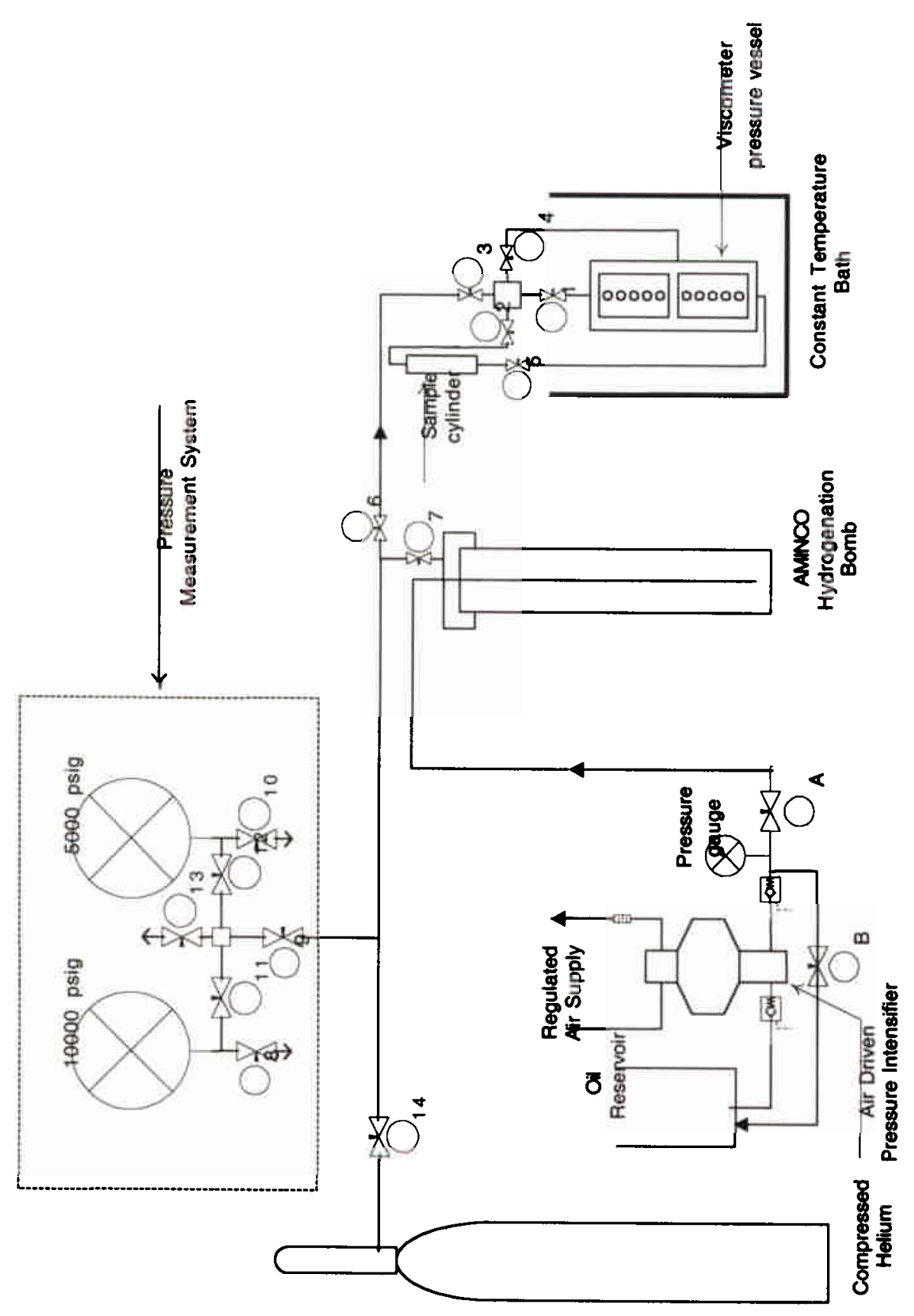

Figure 7. High Pressure Viscometer Setup 
Viscosity of Diesel - DME Blends

The high pressure viscometer capillary was calibrated using a CANNON Certified Viscosity Standard N 1.0. Mass was used as the controlled variable in determining the composition of the samples.

Table 1 shows the samples used for viscosity measurement.

Table 1. Samples for Viscosity Measurement

\begin{tabular}{|c|c|}
\hline Sample number & Percent of DME by Mass \\
\hline 1 & 100 \\
\hline 2 & 74 \\
\hline 3 & 50 \\
\hline 4 & 26 \\
\hline 5 & 0 \\
\hline
\end{tabular}

The remaining portion of the sample was made up by Emissions Certification Diesel Low Sulfur (ECD-LS) from Specified Fuels of Channelview, TX. Figure 8 shows the effect of ambient pressure on the viscosity of the various liquid samples. The kinematic viscosity is plotted on a logarithmic scale. R.H. Johnson notes that a plot of the logarithm of the kinematic viscosity versus the pressure results in a straight line. The slope of this line can be used to extrapolate to higher pressures with a fair amount of accuracy. 


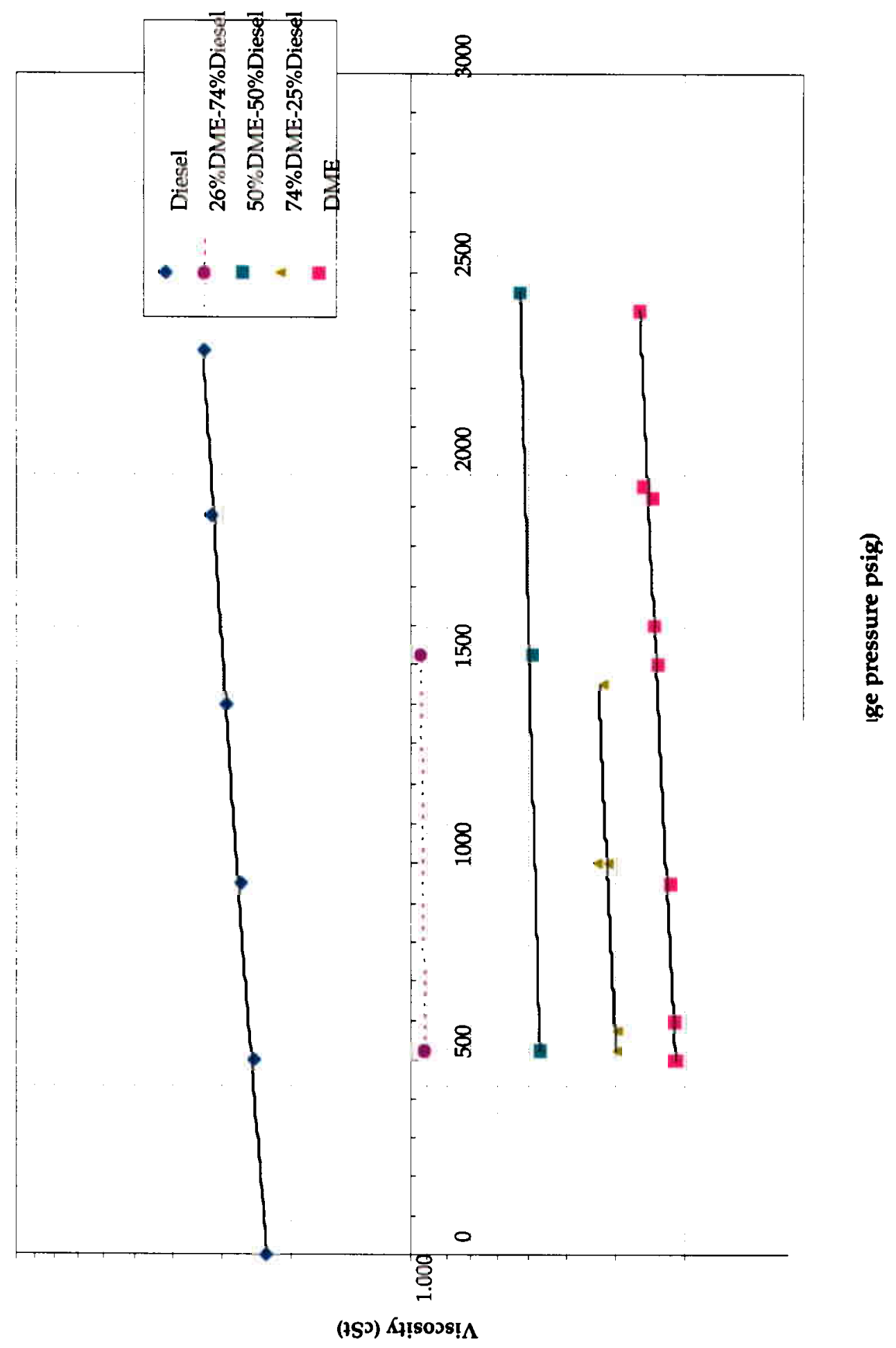

Figure 8. Pressure-Viscosity Relationship for Diesel-DME Samples @ 100 F 
The line representing the 49 State Reference Diesel fuel starts from ambient pressure. For the remaining samples with DME as a constituent, the starting point was 500 psig to ensure that the samples remain in a liquid state. The pressure range in which the viscosity measurements are made are typical in the low pressure circuit of a diesel engine. Previous studies, done with pure DME as the fuel, state that lower injection pressures can be used for DME as the condition in the cylinder just before the firing TDC allows a very rapid vaporization of DME.

Another use of the viscosity versus pressure relations for the various blends is to choose or design a fuel injection system for the optimized blend ratio. There are two ways in which the fuel system can be designed for an engine running on a Diesel-DME blend. The first one is to examine the capability of an existing fuel systems. The deciding factor in this case will be the minimum viscosity than an existing fuel injection system can handle. The other way would be to optimize a blend ratio for a particular engine considering the exhaust emissions benefits and the energy density tradeoffs and to use the viscosity data of this particular blend to design a fuel injection system.

Figure 9 shows the response of the kinematic viscosity to the ratio of DME in the blend. This graph shows the effect of pressure on the viscosity of a particular blend. This data was used to select the target concentration for operation of the campus shuttle bus on DME-diesel fuel blends. At $25 \mathrm{wt} . \%$ DME addition, the viscosity of the blend is already below the ASTM diesel fuel specification. So, $25 \mathrm{wt} \%$ is the maximum DME content on which the engine should operate.

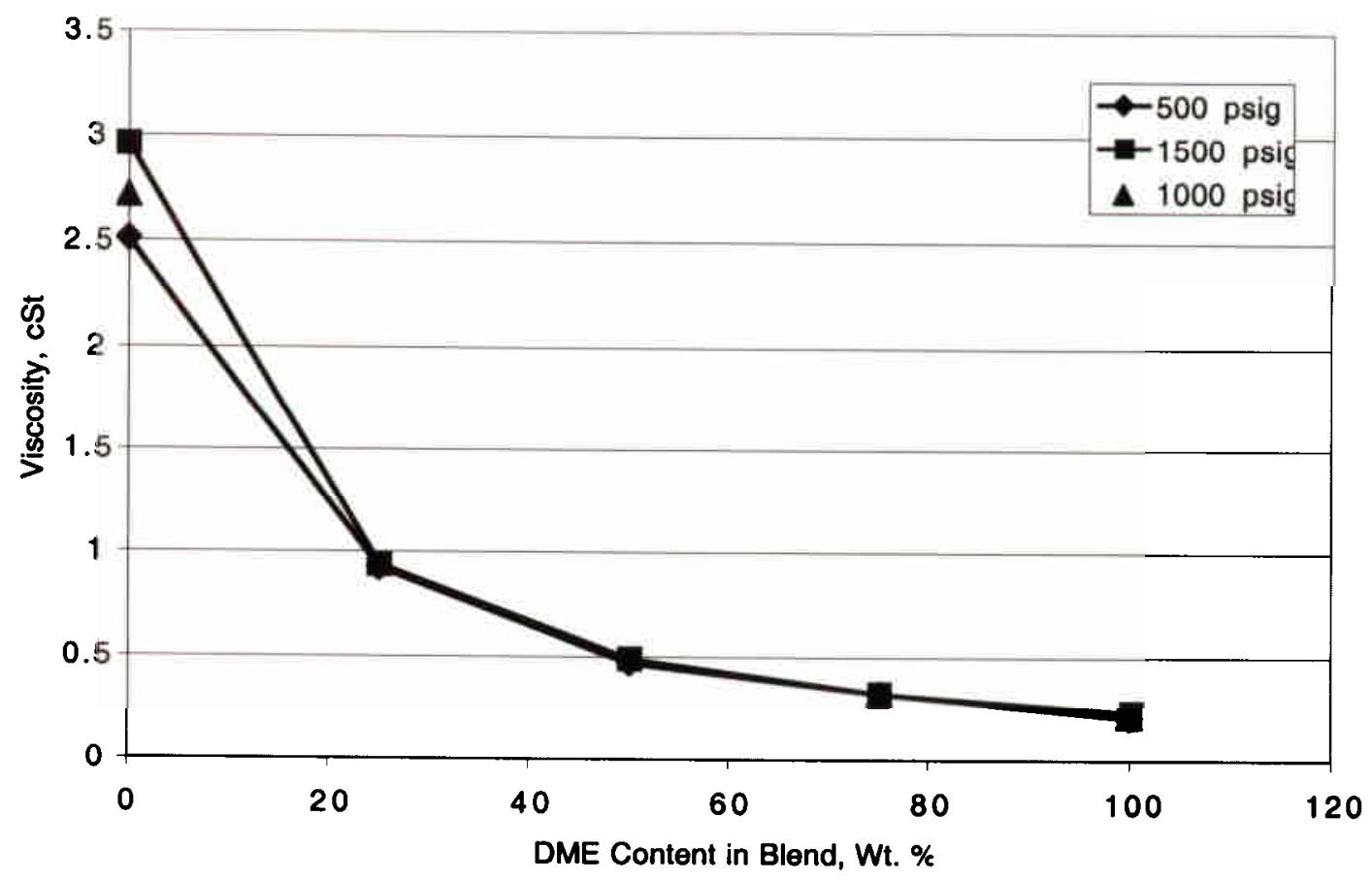

Figure 9. Viscosity - DME Content Relationship at Different Pressures@100 F 


\section{Fuel Station Construction And Bus Conversion}

\section{Fuel Station Construction}

Initially an in depth research and design project was undertaken for a large-scale permanent DME fueling station. The fueling station consisted of two DME storage tanks, one diesel tank, and one tank for the mixed fuel. The station was designed to utilize two transfer pumps: the DME/mixed fuel pump to perform at 10 gallons per minute (GPM) and the diesel transfer pump to perform at 100GPM. Extreme attention was given to the material of the inner seals/O-rings in the $\mathrm{DME} /$ mixed transfer pump. The system was designed to utilized helium as the gas to provide the necessary over pressure in the DME/mixed tanks.

The final and much less expensive design of the fueling station required only that we make the refueling process more elaborate. By switching to a two step process, we eliminated the need to have a dedicated fueling station. Instead, refueling relies on the existing diesel fuel pumps for University service vehicles to fill the bus' main tank with diesel fuel. Then, the driver will backs up to an adjacent storage location for the DME tank to transfer diesel fuel to the mixture tank containing DME and diesel fuel. The final step is to add the DME to the mixture tank. Figure 10 shows a schematic diagram of the refueling site.

In conjunction with the construction of the fueling station, a "Preparedness, Prevention and Contingency" (PPC) Plan was developed and executed in collaboration with Penn State's office of Environmental Health and Safety. 

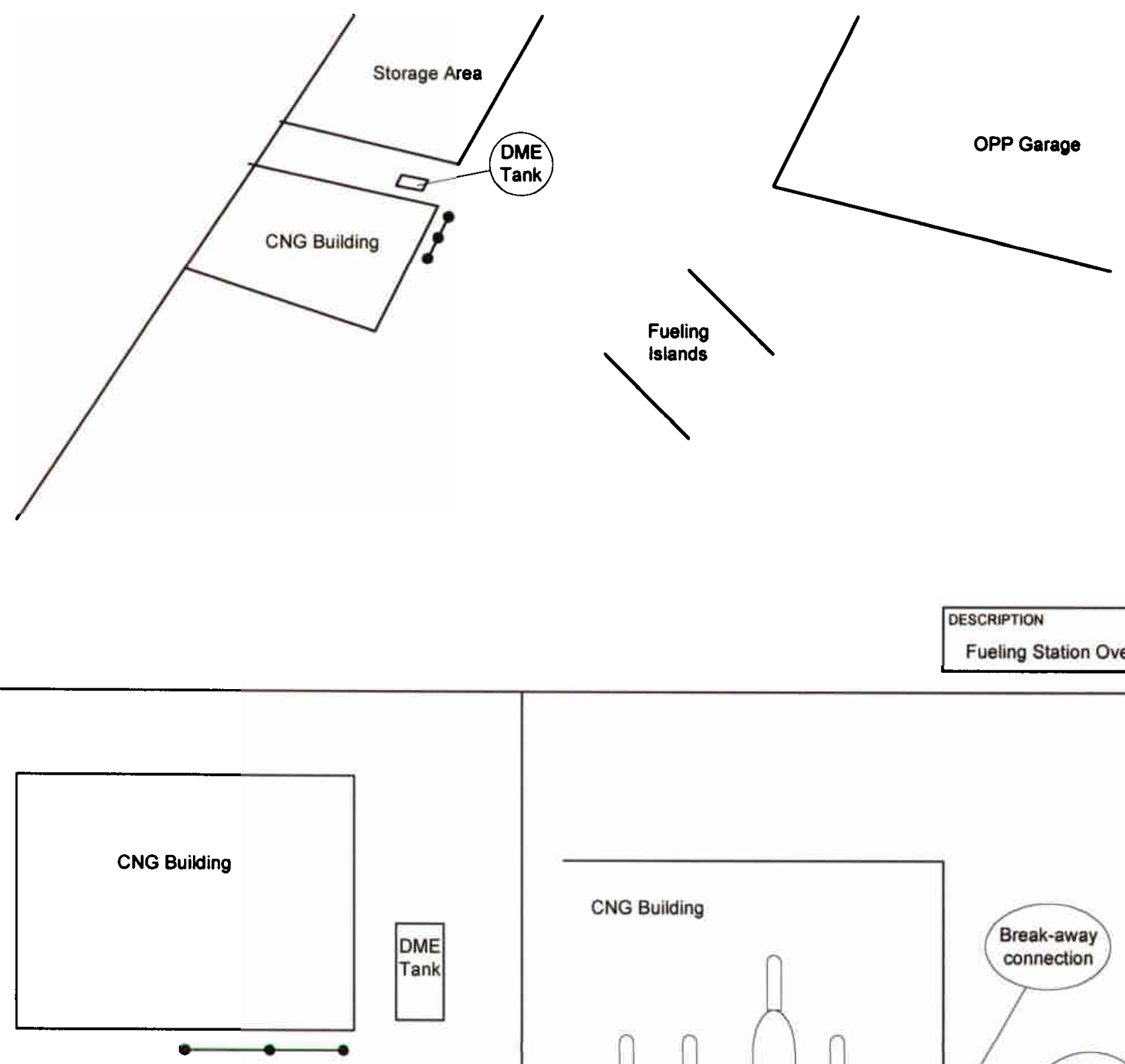


\section{Shuttle Bus Conversion}

For the past two years a fleet vehicle on the campus of The Pennsylvania State University has been undergoing a conversion process to run on an alternative fuel mixture. This fuel, a mixture of diesel fuel and dimethyl ether, requires the use of a pressurized fuel tank and fueling system. The initial design of this system was completed in the laboratories of The Energy Institute at Penn State on an identical engine in an engine test cell. This design was then used as the basis for the system to be implemented on the fleet vehicle. The system on the fleet vehicle started with a schematic of the laboratory setup and evolved into the present day onboard system through a complicated development process which is outlined below.

Phase 1:

This phase starts with the initial system design from the laboratory setup and adapts the design to the necessary operational changes required for use on a fleet vehicle. These issues are mainly limited to fueling procedure and consideration of the interaction between the driver and the fueling system. The system must be designed so that the fueling procedure after the conversion process is relatively easy and efficient.

Phase 2:

This phase starts after a functional design has been achieved. It includes environmental considerations, material compatibility issues, and public safety issues. The conclusion of this phase is the completion of a detailed HAZOP analysis on the final system design layout and determination of any necessary changes to the design before construction begins.

This phase increased the complexity of the design by adding numerous fail safe components such as bypass valves, emergency shutoff valves, pressure relief valves, fill stop valves, pressure gauges, and check valves. In addition these changes and considerations also led to the development of a complicated electrical system to monitor pressure, temperature and fuel level.

\section{Phase 3:}

This phase involved individual component selection, sizing, pricing and purchasing. Due to availability issues and material compatibility issues this phase took the better part of 6 months to complete.

\section{Phase 4:}

This phase consisted of the actual system construction on the bus. The system was constructed on the vehicle in two blocks:

Block 1: All components under the bus and in the passenger compartment are installed. No changes were made to the existing fueling system or engine compartment. This allowed the bus to be operated during times of high demand for fleet vehicles.

Block 2: The bus is removed from service and the factory fueling system was disconnected and the new fueling system connection was made. 
This phase also included constant re-evaluation of design changes as needed.

\section{Phase 5:}

This phase is an actual safety inspection of the completed system on the bus. The inspection was performed by both outside and inside personnel. This phase also served to check the status of open line items in the Hazop analysis and sign off on those items if they were now a non-issue due to design changes or there were completed.

\section{Phase 6:}

This phase is the debugging process and functionality test for the system. It is divided into two sections which are in turn each divided into two blocks.

Section 1: This section involves running the bus on diesel fuel while utilizing the new fueling system. This test is separated into two blocks:

Block 1: The bus is driven at the Pennsylvania Transportation Institute test track facility located in State College Pennsylvania for a distance of no less than 50 miles. This serves to evaluate the structural integrity of the system and its functionality.

Block 2: The bus is operated on the Penn State campus while under supervision from Energy Institute staff. The purpose of which is to orient the fleet drivers and passengers to the on-board changes. This block also serves to evaluate the systems performance in the buses normal environment.

The completion of this section is a leak check of the system by both a visual and physical inspection.

Section 2: This section is similar in structure to section 1 with the addition of the DiMethyl ether into the system. Again the section is separated into two blocks:

Block 1: The bus is driven at the Pennsylvania Transportation Institute test track facility located in State College Pennsylvania for a distance of no less than 50 miles. This serves to evaluate the structural integrity of the system and its functionality.

Block 2: The bus is operated on the Penn State campus while under supervision from Energy Institute staff. The purpose of which is to orient the fleet drivers and passengers to the on-board changes. This block also serves to evaluate the systems performance in the buses normal environment.

The completion of this section and this phase is a final leak check of the system by both a visual and physical inspection.

During the debugging in this phase, one problem was consistent. The circulation pump that moves fuel through the engine rail and then to the fuel coolers was shutting off. The inverter that powered this pump was not able to provide enough power fast enough so a new one was purchased. 
The problem remained after this changed and the manufacture suggested a larger motor. A larger motor was purchased and installed and a new larger inverter was purchased.

These two changes eliminated the pump shutoff problem however a new problem became evident. The pump would operate for varying lengths of time before beginning to display symptoms of cavitation. The pump manufacturer suggested that the pump was in fact decoupling and that the magnetic coupler should be inspected. The pump was removed and the coupler inspected. The magnets inside the coupler were found to be destroyed (as seen below) and the coupler was replaced. Additional fuel coolers were installed during this down time to eliminate any two-phase flow due to heat soak. 
Gauges

G1 Magnetic level gauge

in tank

G2 DP across P2

G3 Pressure transducer

G4 Level indicator T1

G5 Temperature

Heat Exchangers

E1 finned tube
E2 finned tube
Pumps

1 Transfer pump

P2 Tuthill pump

Regulators

$R 1$ He regulator on

(T3)

$\mathrm{R} 2 \mathrm{He}$ regulator on

(T4)
Janks

T1 Diesel tank

T2 Mix tank T3 Helium tank

T4 DME tank

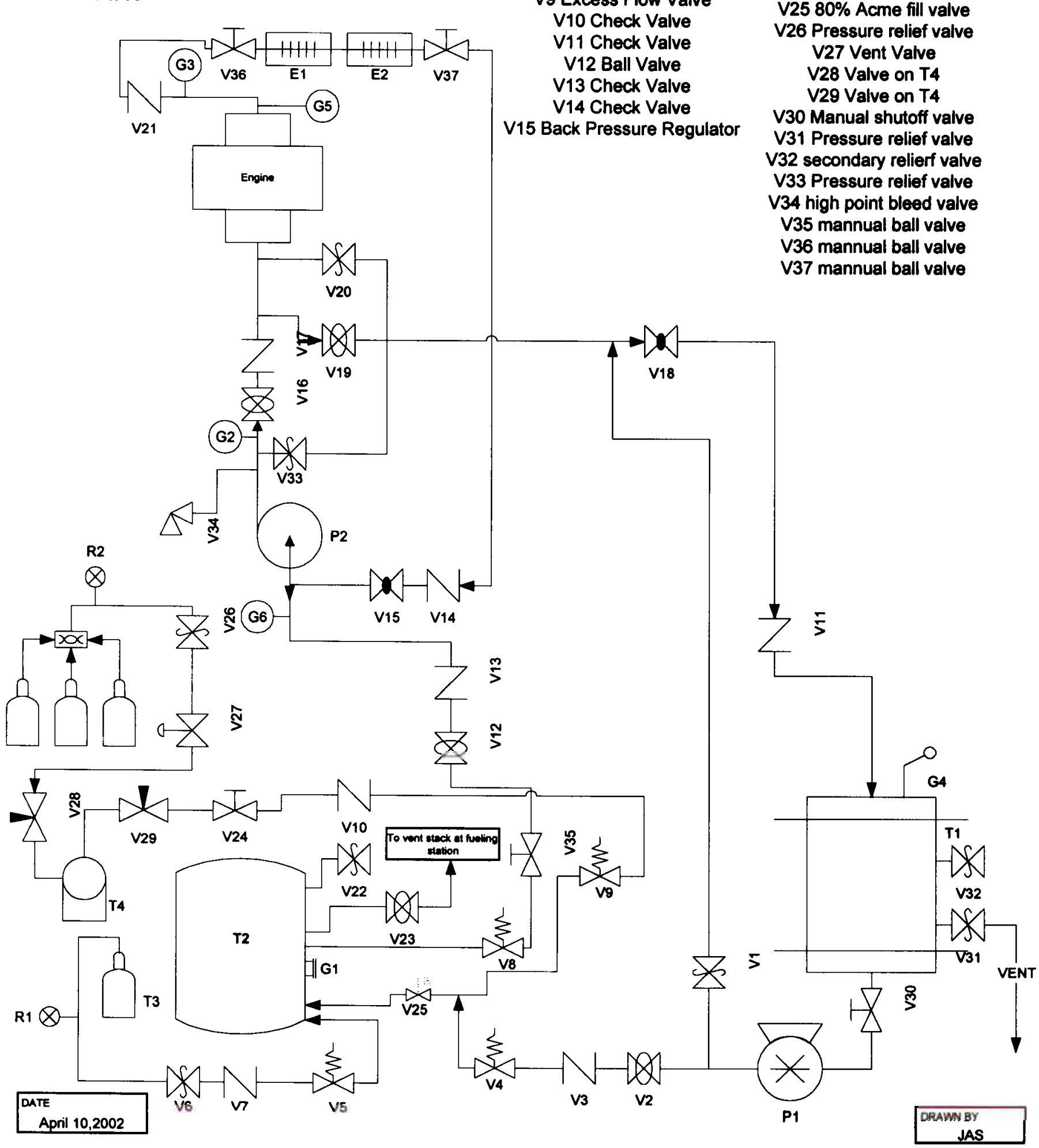

Figure 11. Schematic diagram of DME-diesel fueling system on the shuttle bus 


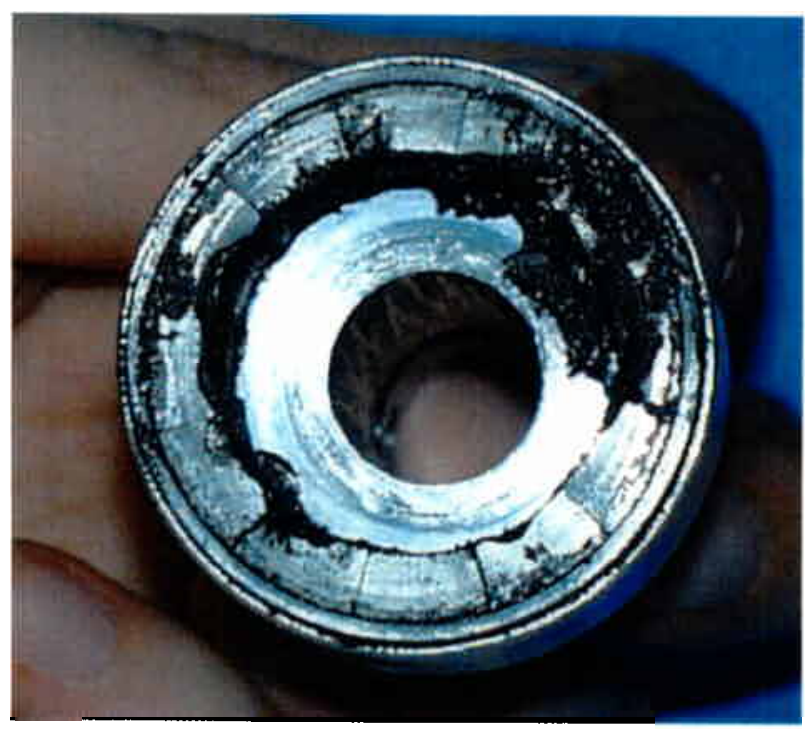

Figure 12. Damaged magnetic coupling from Tuthill gear pump

After replacing the coupler the pump was re installed and work flawlessly for several weeks before the same symptoms of cavitation became evident. Again the coupler was inspected but this time it was found to be undamaged. Instead, the pump head internally had developed an operational problem, greatly increasing the torque required to rotate the pump. The manufacturer was contacted and currently a new pump head is being shipped.

Finally, Figures 13 and 14 show digital photos of the shuttle bus after the conversion. These pictures were taken at the event hosted on April 19, 2002 to celebrate the launch of the bus on DME-diesel blends.
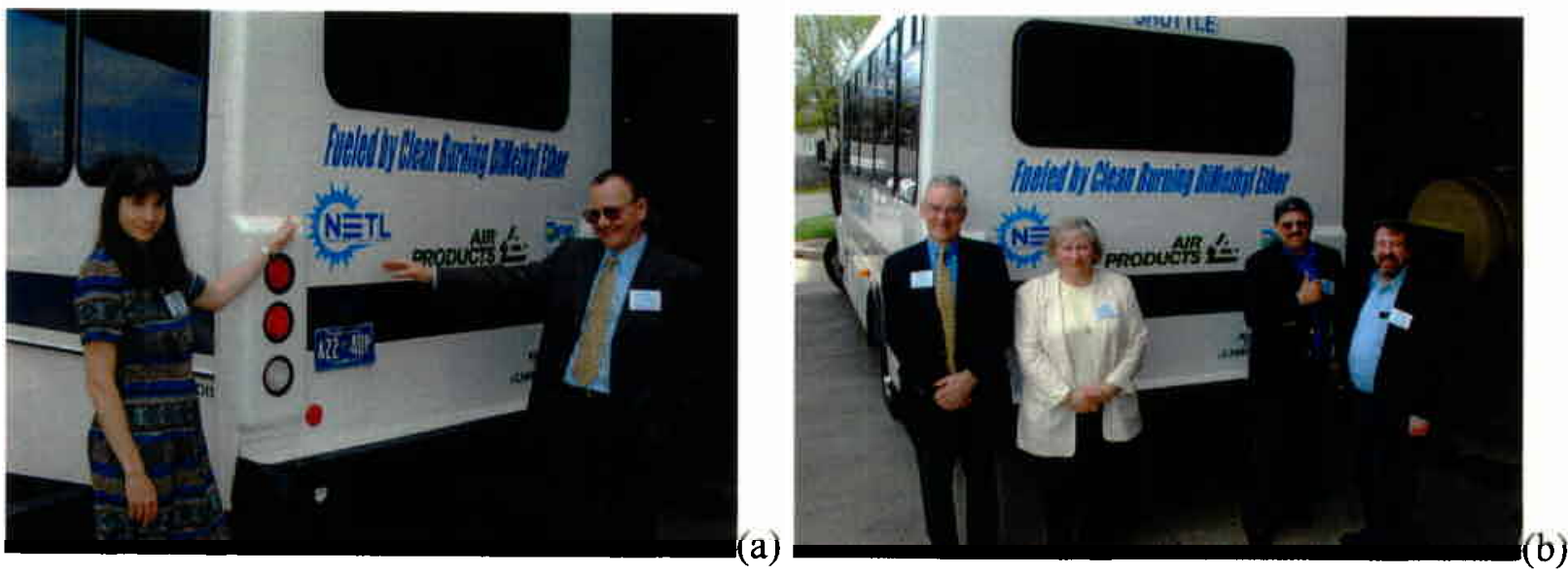

Figure 13. (a) Jenny Tennant and John Winslow of NETL and (b) Jim Sorensen, Jo Ann Franks, Bob Miller and Barry Halper of Air Products and Chemicals, Inc. 


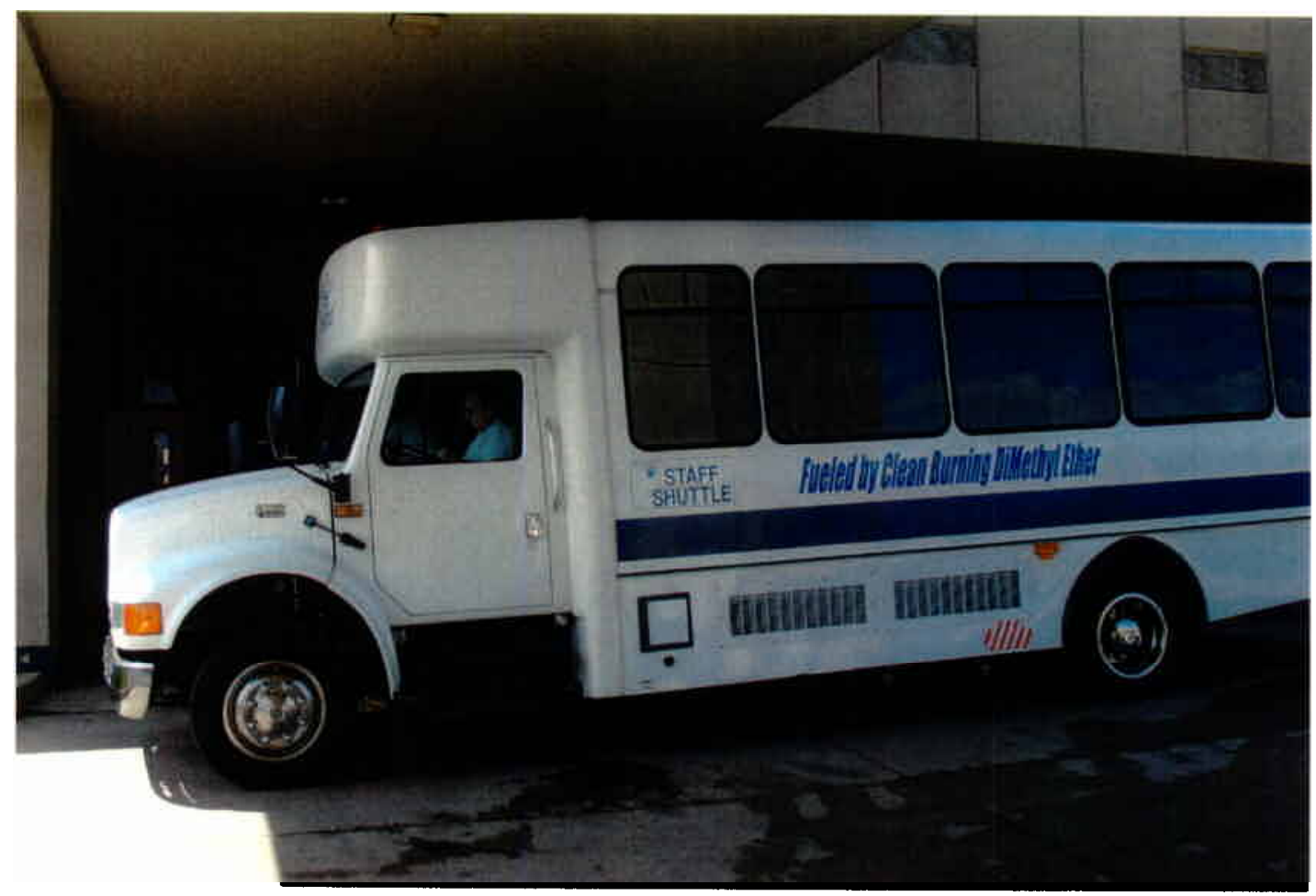

Figure 14. DME-Diesel Fueled Campus Shuttle Bus pulling away during its maiden voyage at the event to celebrate the launch of the bus, April 19, 2002 held at the Penn State Energy Institute. 


\section{CONCLUSION}

The DME-Fueled Shuttle Bus fueling system became operational in February 2002. Preliminary emissions tests and basic operation of the shuttle bus took place at the Pennsylvania Transportation Institute's test track facility near the University Park airport. After modification and optimization of the system on the bus, operation on the campus shuttle route began in early June 2002. However, the work and challenges have continued as it has been difficult to maintain operability of the shuttle bus due to fuel and component difficulties. As of late June 2002, it appears that the pump head itself developed operational problems (loss of smooth function) leading to excessive stress on the magnetic coupling and excessive current draw to operate. A new pump head is being installed on the system to alleviate this problems and get the shuttle bus back in operation. In summary, the conversion is completed but there have been operational challenges in the field. We continue to work to make the shuttle bus as reliable to operate on DME-diesel blends as possible. 


\section{REFERENCES}

1. Chapman, E., Boehman, A. et.al., "Emissions Characteristics of a Navistar 7.3L Turbodiesel Fueled with Blends of Dimethyl Ether and Diesel Fuel". Society of Automotive Engineers, 2001(2001-01-3626).

2. Chapman, E., Bhide, S., Boehman, A. et.al. "Engine Performance and Emissions from fuel blends of Dimethyl Ether (DME) and diesel fuel". in AIChE Spring National Meeting, Session 141- Oxygenated Fuels. 2001. New Orleans, LA, March 10-14, 2002.

3. Kajitani, S., Chen, Z., Konno M, "Engine performance and Exhaust Characteristics of DI Diesel Engine operated with DME". Society of Automotive Engineers, 1997 (972973).

4. Liotta, F.J., and Montalvo,D.M., "The Effects of Oxygenated Fuels on Emissions from a Modern Heavy-Duty Diesel Engine". Society of Automotive Engineers, 1993 (932734).

5. Sidhu, S., et.al., "Semi-volatile and particulate emissions from the combustion of alternative diesel fuels". Chemosphere, 2001. 42: p. 681-690. 


\section{ACKNOWLEDGMENT}

We are grateful to Air Products and Chemicals, Inc., the Pennsylvania Department of Environmental Protection and the National Energy Technology Laboratory for supporting this work. We would also like to specifically thank Peter Tijm (now with Renntech), Jim Hansel and Barry Halper and Jo Ann Franks of Air Products for many helpful comments and suggestions, Susan Summers of the DEP for her continuing encouragement and support of this project, and Mike Nowak, Jenny Tennant and John Winslow for their support and guidance. We are grateful to Dr. Pranab Das and David Schuh of Navistar for their support and technical guidance. Finally, we are deeply indebted to Dr. Harold Schobert, Director of the Energy Institute, for his generous financial support of the development of our laboratory facilities.

During the course of the shuttle bus conversion, a great many members of the Penn State community and various companies have lent assistance to this effort. In particular, the drivers and staff at the Pennsylvania Transportation Institute's Test Track Facility and the manager and staff of the Office of Physical Plant's Garage Services area have been a tremendous help. The companies that have given their assistance include Caterpillar, Parker-Racor, Tuthill Pump, Ober-Read \& Associates, Master Flow Pumps and International Truck. 


\section{APPENDICES}

The appendices include two papers presented during the past year that come directly from work performed under this project. The paper citations are as follows:

Bhide, S.V., Boehman, A.L. and Perez, J.M., "Viscosity of DME-Diesel Fuel Blends," in ACS Fuel Chemistry Division Preprints, 46(2), 400-401 (2001).

Chapman, E.M., A.L. Boehman, P.J.A. Tijm and F.J. Waller. Emission Characteristics of a Navistar 7.3L Turbodiesel Fueled with Blends of Dimethyl Ether and Diesel Fuel. Society of Automotive Engineers Technical Paper No. 2001-01-3683. Was to be Presented at the 2001 SAE Fall Fuels and Lubricants Meeting, San Antonio, TX, September, 2001. 
VISCOSITY OF DME-DIESEL FUEL BLENDS

Shirish V. Bhide, André L. Boehman and Joseph M. Perez

The Energy Institute

The Pennsylvania State University

405 Academic Activities Building

University Park, PA 16802

\section{Introduction}

The need to reach ever tightening NOx and particulate emissions standards has placed a tremendous amount of pressure on the fuel, lubricant, engine and vehicle manufacturers. However, in the 1990's studies of direct injection diesel engines fueled by dimethyl ether demonstrated particulate emissions below the ULEV standard and $\mathrm{NO}_{\mathrm{x}}$ emissions that approach or achieve ULEV levels, without exhaust aftertreatment $[1,2]$. Until those tests, DME had not been considered as a primary replacement fuel. Previously, DME had been considered as a methanol ignition improver for methanol powered vehicles [3-6]. At present, the predominant use for DME is as an environmentally benign aerosol propellant, since DME is nontoxic and is easily degraded in the troposphere [7]. Recent work on DME has focused on its use in advanced technology, direct-injection (DI) engines as a neat fuel [8-12].

However, DME has significantly different physical properties than diesel fuel including a low critical point, low viscosity, negligible lubricity and a high vapor pressure. In the present work, DME has been blended into diesel fuel to obtain a fuel mixture that retains the desirable physical properties of diesel fuel but includes the cleaner burning capability of DME. The miscibility and viscosity of blends of DME and diesel fuel were characterized using pressurized, optically accessible instrumentation. These physical property measurements are part of a comprehensive study of the operation of a turbodiesel engine on DME-diesel blends which is leading to a field demonstration of this fueling strategy [13].

\section{Experimental}

Two different high pressure cells were adapted for studying the miscibility and viscosity of blends of DME and diesel fuel. One permitted the fuel mixtures to be held at pressures up to 200 psi to examine miscibility by visual inspection of blends over extended periods of time. The fuels were deemed to be miscible if no evidence of phase separation was observed. The other instrument is a high pressure viscometer based on a capillary tube held within a pressurized chamber suitable for measurements at pressures up to 3500 psi.

Miscibility Measurements. Qualitative studies of the miscibility of blends of DME and a federal low sulfur (300 ppm) "emissions certification" diesel fuel (Specified Fuels "ECD LS") were performed under pressures above 90 psi. Blends from $25 \mathrm{wt} . \%$ DME up to 75 wt.\% DME in diesel fuel were examined. Diesel fuel was gravity fed into an optically accessible pressure chamber, while DME was delivered from a cylinder of liquefied DME through an opening in the bottom of the pressure chamber. Pressures in the chamber were raised by feeding nitrogen above the fuel mixture to attain 90 psi or greater in the chamber.

Viscosity Measurements. Quantitative measurements of the viscosity of blends of DME in the federal low sulfur fuel were obtained using a high pressure viscometer, using capillary tubes that provided optimal measurement accuracy depending on the viscosity of the fuel mixture. Figure 1 shows a photograph of the high pressure chamber where the capillary tubes are located.

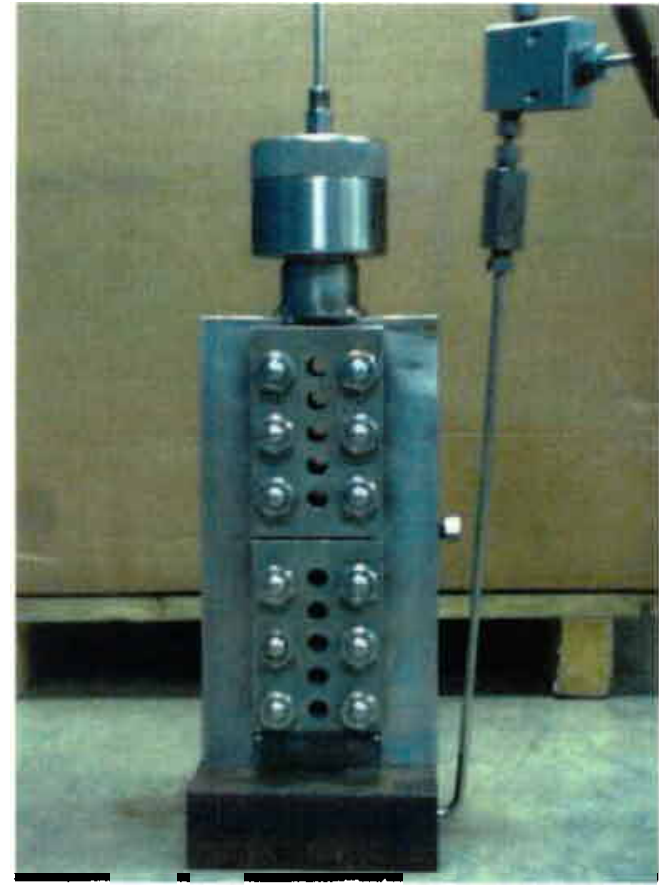

Figure 1. High pressure viscometer housing.

Figure 2 shows the rest of the viscometer system, which includes a pressure intensifier and pressure gages for generation of pressures up to $3500 \mathrm{psi}$ with the chamber.

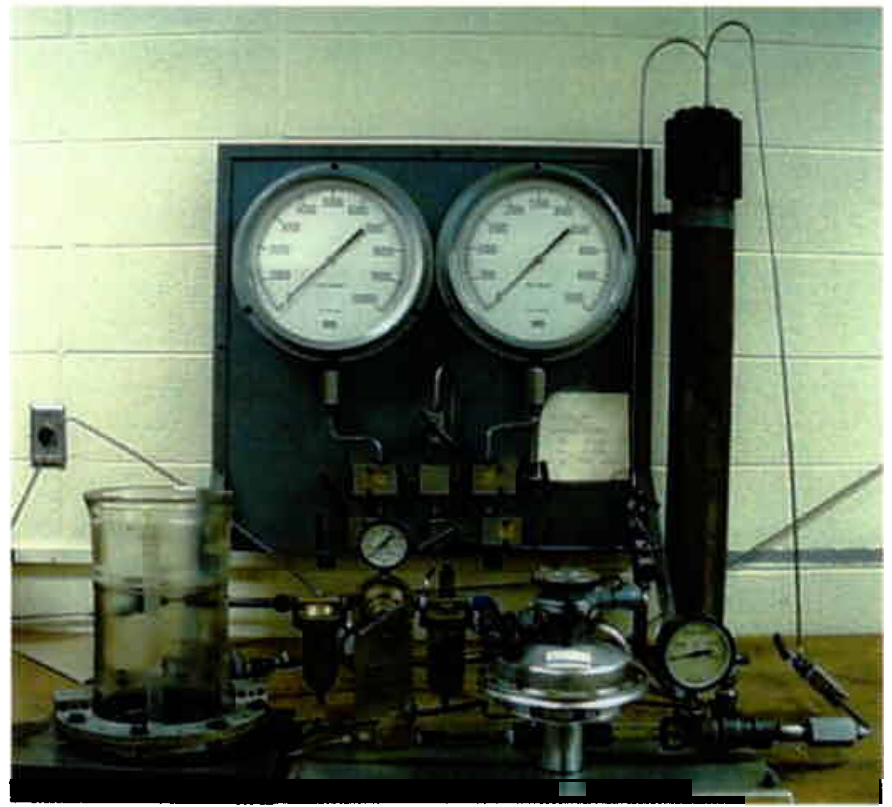

Figure 2. Supporting instrumentation for the high pressure viscometer.

\section{Results and Discussion}

Miscibility Measurements. The DME was observed to rapidly mix uniformly with the diesel fuel at all blend ratios. Over time, a blend that was initially not well mixed would become uniform, but injection of the DME from below the pool of diesel fuel was a particularly effective means of rapidly obtaining a uniform mixture.

Viscosity Measurements. Observations of the viscosity of the blends of DME and diesel fuel are summarized in Figure 3. Measurements were obtained over a range of pressures with the viscometer housing immersed in a constant temperature bath at $100^{\circ} \mathrm{F}$ $\left(38^{\circ} \mathrm{C}\right)$. Results obtained at three different levels of chamber pressure 
are plotted in Figure 4 to show the impact of DME content on viscosity.

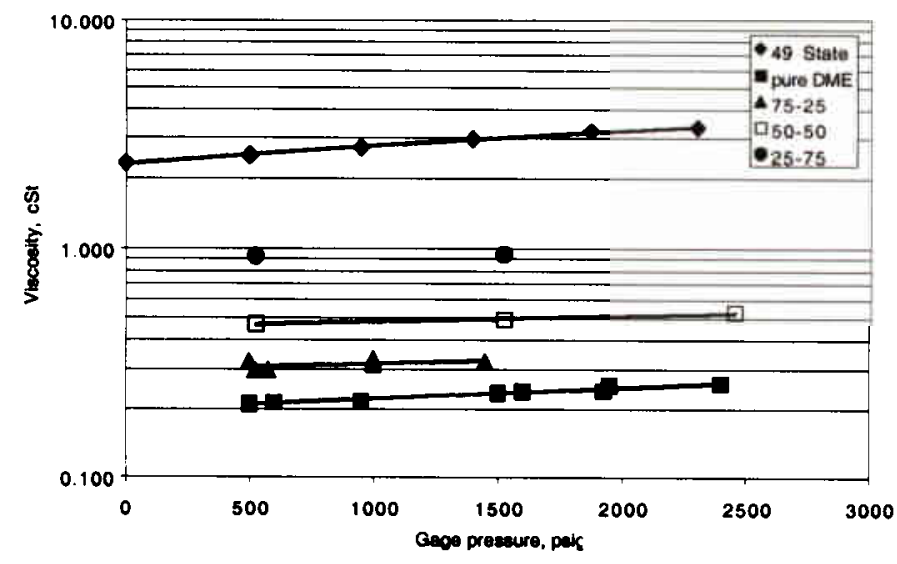

Figure 3. Viscosity of DME-diesel blends at pressures from 500 to 2500 psi.

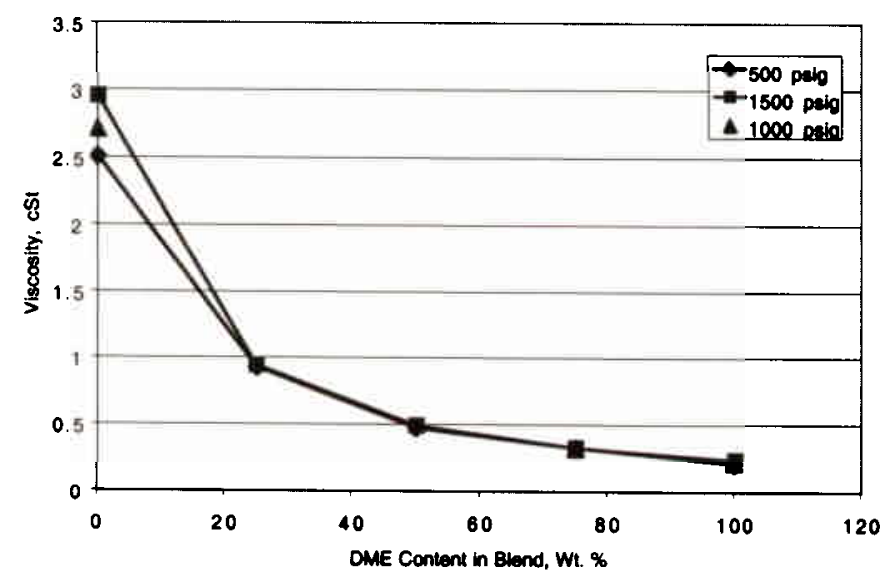

Figure 4. Blend response of viscosity to DME addition at various pressures.

These two figures show that viscosity decreases rapidly at low levels of DME addition. For instance at $25 \mathrm{wt} \%$ DME addition, viscosity falls by more than a factor of 2 , from the more than $2.5 \mathrm{cSt}$ value of the neat diesel fuel to roughly $1 \mathrm{cSt}$. This non-linear blending response demonstrates that even modest addition of DME to diesel fuel brings the fuel blend below the ASTM diesel viscosity specification of $1.39-4.20 \mathrm{cSt}$ at $40^{\circ} \mathrm{C}$.

These viscosity measurements are among the first reported for DME under elevated pressures and are the first reported for blends in diesel fuel. Recent work by Sivebaek et al. [14] also considered the viscosity of DME, in particular with addition of lubricity and viscosity enhancing additives. They developed a volatile fuel viscometer (VFVM) that was designed to handle DME, neat or additized. They measured kinematic and dynamic viscosities of pure DME of $0.185 \mathrm{cSt}$ and $0.122 \mathrm{cP}$ at $25^{\circ} \mathrm{C}$, which compares well with the present study. Their measurements were performed at 5 bar pressure, roughly $75 \mathrm{psi}$. In the present study, no DME blends were examined at a pressure below $500 \mathrm{psi}$, but at this pressure the viscosity of neat DME was found to be $0.21 \mathrm{cSt}$. Extrapolating data for neat DME from the present study to a pressure of 75 psi yields an estimate of $0.2 \mathrm{cSt}$, which is in reasonable agreement with the value of $0.185 \mathrm{cSt}$ obtained by Sivebaek et al. They also concluded that additized DME cannot reach the same viscosity and lubricity as diesel fuel. They suggest that rather than using additives to allow fuel systems to tolerate DME, the solution is to design the pumps so that they can handle pure DME.

\section{Conclusions}

Blending DME in diesel fuel is one option to utilize DME in diesel engines without drastic redesign of fuel pumps and fuel injectors. However, even modest addition of DME into diesel fuel significantly reduces the viscosity of the fuel mixture. Addition of as little as $25 \mathrm{wt}$ \% DME into diesel fuel reduces fuel viscosity below the ASTM specification. This suggests that viscosity rather than miscibility is the limiting factor in blending DME with diesel fuel.

Acknowledgement. The authors wish to acknowledge the support of Air Products and Chemicals, Inc., the Pennsylvania Department of Environmental Protection and the National Energy Technology Laboratory of the U.S. Department of Energy. In particular, the authors wish to acknowledge the support and encouragement of John Winslow, Mike Nowak and Jenny Tennant of NETL and Peter Tijm (now with Renntech), Barry Halper, Jo Ann Franks and James Hansel of Air Products.

This paper was written with support of the US Department of Energy under Contract no. DE-FG29-99FT40161. The Government reserves for itself and others acting on its behalf a royalty-free, nonexclusive, irrevocable, worldwide license for Governmental purposes to publish, distribute, translate, duplicate, exhibit and perform this copyrighted paper.

\section{References}

(1) Fleisch, T., McCarthy, C., Basu, A., Udovich, C., Charbonneau, P., Slodowske, W., Mikkelson, S.-E., and McCandless, J., 1995, SAE paper no. 950061 .

(2) Kapus, P. E., and Cartellieri, W. P., 1995, SAE paper no. 952754.

(3) Karpuk, M. E. and Cowley, S. W., 1988, SAE paper no. 881678.

(4) Green, C. J., Cockshutt, N. A. and King, L., 1990, SAE paper no. 902155 .

(5) Murayama, T., Chikahisa, T., Guo, J., and Miyano, M., 1992, SAE paper no. 922212 .

(6) Guo, J., Chikahisa, T., Murayama, T., and Miyano, M., 1994, SAE paper no. 941908 .

(7) Hansen, J. B., Voss, B., Joensen, F., and Siguroardottir, I. D., 1995, SAE paper no. 950063.

(8) Wilson, R., Diesel Progress Engines and Drives, 1995, June 1995, pp. 108-109.

(9) Fleisch, T. H., Diesel Progress Engines and Drives, 1995, October 1995, pp. 42-45.

(10) Glensvig, M., S. C. Sorenson and D. L. Abata, ASME Paper No. $97-$ ICE-67, 1997, in ICE-Vol. 29-3, pp. 77-84.

(11) McCandless, J. C. and Li, S., 1997, SAE paper no. 970220.

(12) Alam, M., O. Fujita, K. Ito, S Kajitani, M. Oguma and H. Machida, 1999, SAE paper no. 1999-01-3599.

(13) Chapman, E. M, Bhide, S. V., Boehman, A. L., Tijm, P. J. A. and Waller, F. J., 2000, SAE paper no. 2000-01-2887.

(14) Sivebaek, I. M., Sorenson, S. C., and Jakobsen, J., 2001, SAE paper no. 2001-01-2013. 


\title{
Emission Characteristics of a Navistar 7.3L Turbodiesel Fueled with Blends of Dimethyl Ether and Diesel Fuel
}

\author{
Elana M. Chapman and André L. Boehman \\ The Pennsylvania State University \\ Peter Tijm \\ Rentech, Inc. \\ Francis Waller \\ Air Products and Chemicals, Inc.
}

Copyright $\odot 2001$ Society of Automotive Engineers, Inc.

\begin{abstract}
Several oxygenates have been proposed and tested for use with diesel fuel as a means of reducing exhaust emissions. This paper examines dimethyl ether (DME), which can be produced in many ways including via Air Products and Chemicals, Inc's Liquid Phase Technology (LPDME TM). Modest additions of DME into diesel fuel (2 wt.\% oxygen) showed reductions in particulate matter emissions, but the previous data reported by the author from a multicylinder Navistar 7.3L Turbodiesel engine were scattered. In this study, experiments were performed on a multi-cylinder Navistar 7.3L Turbodiesel engine to repeatably confirm and extend the observations from the earlier studies. This is an important step in not only showing that the fuel does perform well in an engine with minor modifications to the fuel system, but also showing that DME can give consistent, significant results in lowering emissions. The DME and diesel blends tested were to achieve a net addition of 5 and $10 \mathrm{wt}$. \% oxygen in the blended fuel. The data confirms that the addition of DME can reduce the particulate emissions from a compression ignition engine. However, the $\mathrm{NO}_{x}$ emissions were not favorable for all conditions. It is believed that through further modification of injection timing, $\mathrm{NO}_{x}$ emissions can be effectively reduced.
\end{abstract}

\section{INTRODUCTION}

Demand for cleaner burning diesel fuels is growing worldwide, as governmental regulations make emissions reductions necessary. In the U.S., future regulations that take effect in 2004 and 2007 will require diesel engine and vehicle manufacturers to review all aspects of the vehicle system design [1]. To achieve substantial reductions in emissions, it is thought that reformulated diesel fuels will play an important role. The reformulation of diesel fuels could include lowering the sulfur content, lowering the aromatic content, or potentially the addition of oxygen within the fuel.

A solution for reducing emissions from future and current diesel vehicles is to modify the fuel, without the need to modify the engine hardware. It has been shown that many oxygenates are effective at reducing particulate emissions from diesel engines [2-21]. Therefore, much research has focused on screening of oxygenated fuel additives, including alcohols, esters and ethers. Of particular interest are the glycol ethers, which have been shown to be very effective as blends and as neat fuel. This study focuses on the use of dimethyl ether, which has the chemical formula: $\mathrm{CH} 3-\mathrm{O}-\mathrm{CH} 3$.

Dimethyl ether is a common chemical used as an aerosol propellant [22]. The properties of DME are given in Table 3, and are compared to the diesel fuel used for the baseline testing for this experiment. DME is a liquid at low pressure and standard temperature, and is relatively easy to handle. Over the past ten years, researchers have begun to consider the use of DME as a fuel. Because the Cetane number and ignition temperature are close to that of diesel fuel, DME was thought to be an excellent substitute for use in compression ignition engines. However, there were some drawbacks to using the fuel, including the reduced viscosity and lubricity of the fuel in neat form, as well as fuel compressibility effects $[23,24]$.

To potentially overcome the fuel property effects of DME, as well as reduce emissions, the experiments for this study focus on mixing dimethyl ether with diesel fuel. 
The initial goal is to determine the effect of the oxygen concentration on the emissions, with minimal engine modifications. In this part of the work, no changes have been made to the fuel injection timing, fuel injectors, or engine programming. Changes to the fuel system have been made to allow for the fuel to be delivered to the common rail as a liquid by maintaining the DME-diesel blend at over $100 \mathrm{psi}$.

Over the last ten years, many researches have begun to evaluate the performance and emissions effects of neat dimethyl ether. Sorenson and Mikkelsen [25] found that for a fixed speed and across various loads, the particulate and $\mathrm{NO}_{\mathrm{x}}$ emissions from a .273 Liter direct injection single cylinder engine fueled with neat dimethyl ether could be significantly reduced as compared to emissions when fueled with diesel. In the same study, the $\mathrm{HC}$ and $\mathrm{CO}$ emissions showed little to no change. Later, Sorenson and Mikkelsen [26] further studied the $\mathrm{HC}$ emissions from this same engine, and found that there was an increase in the $\mathrm{HC}$ emissions when using neat DME, with more methane found than in a typical diesel engine, and less light hydrocarbons. With another engine, Christensen and Sorenson [27] looked at various effects on the suite of emissions when using neat DME. Of particular interest, the $\mathrm{NO}_{x}$ emissions were significantly reduced when the injection timing was retarded towards Top Dead Center (TDC). However, there was an increase in the $\mathrm{CO}$ emissions, and little effect on the HC emissions. Other effects tested determined that lower injector opening pressure reduces $\mathrm{NO}_{\mathrm{x}}$, and nozzle types did not seem to influence $\mathrm{NO}_{\mathrm{x}}$ emissions. Experiments completed by Kajitani and coworkers [28] also supported effects of injection timing on reducing $\mathrm{NO}_{\mathrm{x}}$, and having little effect on $\mathrm{HC}$ emissions, from a single cylinder Yanmar engine fueled with neat DME.

However, in the work completed by Hupperich and coworkers [29] with a 1.75 liter single cylinder engine for the ECE R49 13-mode test, the cumulative emissions show some differing results. With the use of neat DME, $\mathrm{HC}$ emissions are reduced. The trends with the other emissions are similar to what had been determined with previous studies. One difference to note is the change in injection nozzle size, which may have effected the emission results in allowing for more complete combustion of all fuels tested in an effort to maintain consistent conditions.

Recently, experiments completed by lkeda and coworkers [30] with a single cylinder engine using a binary fuel injection method, showed similar $\mathrm{NO}_{\mathrm{x}}$ emissions between diesel fuel and 40\% DME mixed with diesel fuel, as injection timing was retarded. Also, HC emissions increased and smoke emissions were reduced as injection timing was retarded. In addition, comparisons were made as a function of BMEP. $\mathrm{NO}_{\mathrm{x}}$ was reduced, HC remained constant and smoke increased with increasing Brake Mean Effective Pressure (BMEP). The experiments also included \% DME fractions, but no comparisons were made to the baseline diesel fuel.
Many researchers have been evaluating the performance of other oxygenates including blends of glycol ethers with diesel fuel, and have observed decreases in particulate matter emissions with increasing oxygenate concentration. Most recently, Hallgren and Heywood [31] prepared a review of the collection of work which showed that as the oxygen content of the fuel increases, the particulate matter is reduced, suggesting that this occurs regardless of chemical structure or molecular weight. However, their actual testing showed that the oxygenate structure did impact particulate emissions. Studies completed by Hess et al. [10] as well as by Litzinger and coworkers $[11,12]$ have shown that higher molecular weight glycol ethers are also effective in reducing particulate matter emissions, although to a lesser extent than monoglyme or diglyme.
Although it has been shown that glycol ethers effectively reduce particulate emissions, the fundamental mechanisms of the reduction have not been clearly identified. There has been some work in simulating the ignition and rate mechanism behavior of dimethyl ether in comparison to dimethoxymethane [19]. Also, oxidation mechanisms have been proposed for gaseous forms of DME [32-34]. Limited data is available for many of the liquid oxygenates under consideration.

For this experimental work, an Emissions Certification Diesel-LS, provided by Specified: Fuels \& Chemicals, LLC., used in combination with dimethyl ether, was evaluated in a multi-cylinder direct injection (DI) engine. In-cylinder pressure measurements provided information about the impact of the oxygenated fuel on the combustion process. In addition, fuel property tests were performed on the base fuels, as well as for the blended fuels. These measurements were used to understand and describe the combustion behavior. Since dimethyl ether is a vapor at 1 atm, the fuel property tests for the fuel blends were performed under pressure to maintain the DME in a liquid state. Because not all tests could be performed, data for DME reported in literature is used for most values. Therefore, the fuel system of the engine was redesigned to accommodate the pressurized fuel delivery. 


\section{EXPERIMENT}

TEST ENGINE- For the purpose of studying the effects of fuel additives on light-medium duty diesel combustion, a Navistar T444E 7.3L Turbodiesel engine was coupled to a 450 horsepower Eaton (Model AD1802) eddy-current dynamometer. The specifications for the engine are given in Table 1. A Pentium PC with Keithley Metrabyte DAS- 1800 data acquisition card was connected to the engine to log real-time engine parameters. These parameters included engine speed, torque, and power from the engine. A Modicon PLC was used to record temperatures from the engine, as well as, for the entire experimental system. Intake airflow rates were determined via an electronic flow sensor, which was calibrated using a laminar flow element. Fuel consumption was monitored using a precision Sartorius scale (Model EA60EDE-1), with an accuracy of \pm 2 grams. Figure 1 shows the test cell set up, and additional equipment used for emissions monitoring.

Table 1. Characteristics of the 1998 Navistar T444E 7.3L Turbodiesel engine

\begin{tabular}{|l|l|}
\hline Displacement & 444 cu.in. (7.3 Liter) \\
\hline Bore & 4.11 inch (104.39mm) \\
\hline Stroke & 4.18 inch (106.20mm) \\
\hline Rated Power & 190 HP @2300 RPM \\
\hline Peak Torque & 485 Ibf-ft @ 1500 RPM \\
\hline Configuration & $\begin{array}{l}\text { Turbo charged, Intercooled } \\
\text { (Air-to-Air), Direct Injection }\end{array}$ \\
\hline Injection Scheme & $\begin{array}{l}\text { HEUI- Hydraulically } \\
\text { actuated, electronically } \\
\text { controlled unit injectors }\end{array}$ \\
\hline Low Idle Speed & 700 RPM \\
\hline Features & Split- shot injection \\
\hline Compression Ratio & $17.5: 1$ \\
\hline
\end{tabular}

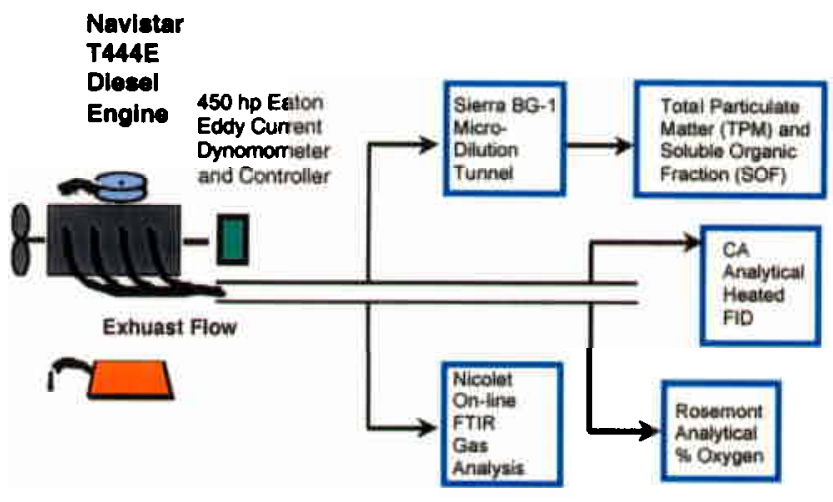

Figure 1. Multicylinder Test Cell, Navistar T444E Turbodiesel

TEST PROCEDURE- In this work, an AVL 8-mode test procedure has been utilized as a model for diesel emissions tests. The AVL 8-mode test was designed to correlate to the U.S. Federal Heavy-Duty Transient Test procedure through a weighted 8- mode steady state test procedure. The 8 modes are a combination of speeds and loads, that produce the same emissions output as would be recorded for a transient cycle [35]. For this engine, the test procedure included the speed and load settings, shown in Table 2.

Table 2. AVL 8-Mode Test for the Navlstar T444E 7.3L Turbodiesel engine

\begin{tabular}{|l|l|l|}
\hline Mode & Speed (rpm) & Load (ft-lb) \\
\hline 1 & 700 & 0 \\
\hline 2 & 876 & 84 \\
\hline 3 & 1036 & 224 \\
\hline 4 & 1212 & 357 \\
\hline 5 & 2300 & 77 \\
\hline 6 & 2220 & 178 \\
\hline 7 & 2220 & 307 \\
\hline 8 & 2124 & 409 \\
\hline
\end{tabular}

EMISSIONS EQUIPMENT- An extended warm-up period was used to prepare the engine for testing. The sampling and measurements during each mode commenced when the exhaust temperatures reached steady state. During this time, RPM and torque were maintained within $1-2 \%$ of the target test conditions. Once steady-state operation was achieved, a portion of 
the exhaust gas was passed through a Sierra Instruments BG-1 micro-dilution test stand with a constant dilution air / sample flow ratio of 8:1 and a total flow of 150 liters/min. These settings were chosen in order to maintain the filter temperature below the EPA specification of $52^{\circ} \mathrm{C}$. Particulate collection occurred on Pallflex 90mm filters (Type EMFAB TX40HI20-WW), conditioned in an environmental chamber at $25^{\circ} \mathrm{C}$ and $45 \%$ relative humidity before and after sampling. Five particulate samples were taken for each fuel at each test mode.

Exhaust gas analyses were completed using a Nicolet Magna 550 Fourier Transform Infrared (FTIR) Spectrometer. For each mode, five gas samples were analyzed for $\mathrm{CO}_{2}, \mathrm{CO}, \mathrm{NO}$ and $\mathrm{NO}_{2}$. Also, a Rosemont Analytical on-line $\mathrm{O}_{2}$ analyzer was used to monitor the percent oxygen in the exhaust gas. The oxygen readings were used in conjunction with the mass flow sensor to determine and verify the air / fuel ratio. Additionally, total hydrocarbon emissions were monitored using a California Analytical Instruments Model 300 Heated Flame Ionization Detector (HFID) Total Hydrocarbon Gas Analyzer. For the total hydrocarbon measurements, undiluted exhaust gas was collected via a heated sample line, which was maintained to $190^{\circ} \mathrm{C}$. Calibration of all equipment was completed prior to each day of testing.

PRESSURE TRACE ANALYSIS- In order to observe the impact of the oxygenated blends on combustion and heat release, the combustion chamber of cylinder 1 of the engine was fitted with a Kistler 6125A pressure probe. The pressure sensor was used with a Kistler 2612 optical crank angle encoder to provide time resolved in-cylinder pressure traces of the combustion event. Pressure, crank angle, and TDC trigger signals were acquired with a Kiethley DAS-1800 data acquisition card operating in a "burst " mode. The pressure traces were analyzed with PtrAn V.02, a software product designed by Optimum Power.

TEST FUELS- Previous work has been completed comparing the increasing percentage of oxygenate mixed with diesel fuels within several types of engines $[9-18,36]$. For this testing, comparisons are made between a $5 \mathrm{wt} . \%$ and $10 \mathrm{wt}$. \% oxygen via blending of DME in diesel fuel. The baseline diesel fuel properties, as well as test fuel properties are given below in Table 3 . Because of the difficulty in obtaining experimentally the fuel blend properties for DME as a liquid, the properties available in the literature for neat DME are represented, as well as linear calculation of the blends.

PRESSURIZED FUEL DELIVERY SYSTEM FOR DIESEL-DME BLENDS -Dimethyl ether (DME) is a liquefied gas. At room temperature and atmospheric pressure, it is a gas, but changes to a liquid at a moderate pressure. DME is currently manufactured by DuPont Fluorochemicals under the trade name Dymel A. For the purposes of the experimental design, information regarding the vapor pressure and density changes with temperature are available in the Technical Information (ATB-25) bulletin from DuPont.

In tests conducted, DME was found to be miscible with \# 2 diesel fuel. Miscibility tests were carried out in a pressurized vessel with a glass observation window. The two fuels were introduced taking care not to mix them. Diesel was introduced first into the bottom of the vessel. DME, which has a specific gravity less than diesel fuel, was then introduced on top of the diesel fuel. Thus, initially there were two distinct layers. The two layers were then observed to mix together without physical agitation after a period of 5 to 6 hours to form a homogeneous mixture. The DME was about $60 \%$ by mass in this mixture. Furthermore, no separation was observed after standing undisturbed for about 3 days.

A schematic of the modified fuel system is shown in Figure 2. The fuel system on the T444E engine had to be modified to account for the need to deliver fuel at elevated pressure. The fuel rail in the cylinder head of the engine receives fuel at a pressure of about 70 psi. Fuel from this rail is then fed to the injectors.

A study was performed using \#2 diesel fuel to measure the temperature rise of the fuel in the fuel rail. This measurement, coupled with the fuel consumption gave an approximate heat transfer rate between the cylinder head and the fuel in the gallery. A maximum target temperature was chosen for the diesel-DME blend based on the vapor pressure curve of DME and the pressure rating of the fuel rail. The required change in fuel recirculation flow rate was then calculated based on the above observations. This recirculated fuel was then cooled down using a water cooled heat exchanger. The fuel delivery pump was sized based on the above calculations.

Table 3. Fuel Properties

\begin{tabular}{|l|l|l|l|l|l|}
\hline $\begin{array}{l}\text { Fuel } \\
\text { Property }\end{array}$ & $\begin{array}{l}\text { ASTM } \\
\text { Method }\end{array}$ & $\begin{array}{l}\text { ASTM } \\
\text { Spec. }\end{array}$ & $\begin{array}{l}\text { Base } \\
\text { Diesel }\end{array}$ & DME & $\begin{array}{l}25 \text { wt\% } \\
\text { DME in } \\
\text { Diesel }\end{array}$ \\
\hline $\begin{array}{l}\text { Viscosity, } \\
40^{\circ} \mathrm{C}, \text { cSt }\end{array}$ & D 445 & $\begin{array}{c}1.39- \\
4.20\end{array}$ & 2.2 & $\begin{array}{r}.25 \\
{[32]}\end{array}$ & $.95[43]$ \\
\hline $\begin{array}{l}\text { API } \\
\text { Gravity }\end{array}$ & D 287 & API 30 & 35.3 & & \\
\hline
\end{tabular}




\begin{tabular}{|l|l|l|l|l|l|}
\hline $\begin{array}{l}\text { Cloud } \\
\left.\text { Point ( }{ }^{\circ} \mathrm{F}\right)\end{array}$ & D 2500 & $<0$ & 4 & & \\
\hline $\begin{array}{l}\text { Pour } \\
\left.\text { Point ( }{ }^{\circ} \mathrm{F}\right)\end{array}$ & D2500 & $<0$ & $<0$ & & \\
\hline $\begin{array}{l}\text { Flash } \\
\left.\text { Point ( }{ }^{\circ} \mathrm{F}\right)\end{array}$ & D 93 & 125 & 166 & -42 & \\
\hline $\begin{array}{l}\text { Calorific } \\
\text { Value } \\
\text { (BTU/lb) }\end{array}$ & D2015 & 19700 & 19483 & 12228 & $17669^{*}$ \\
\hline $\begin{array}{l}\text { Density } \\
\text { (kg/m^3) }\end{array}$ & D4052 & $.845-$ & .848 & .660 & $.801^{*}$ \\
\hline $\begin{array}{l}\text { Cetane } \\
\text { Number }\end{array}$ & D613 & $46-48$ & 47.4 & $>55$ & $>55^{*}$ \\
\hline
\end{tabular}

* Projected

Selecting a pump for DME was challenging due to the properties of DME. Gasket material for the pump had to be modified, as common materials such as Viton and buna- $\mathrm{N}$ have been found to be unsatisfactory. A fuel filter with a high filter surface area and high pressure capacity was needed. A modified propane filter was selected for the application. The fuel tank consisted of a modified $60 \mathrm{lb}$ capacity LPG cylinder which was pressure tested at 120 psi prior to use.

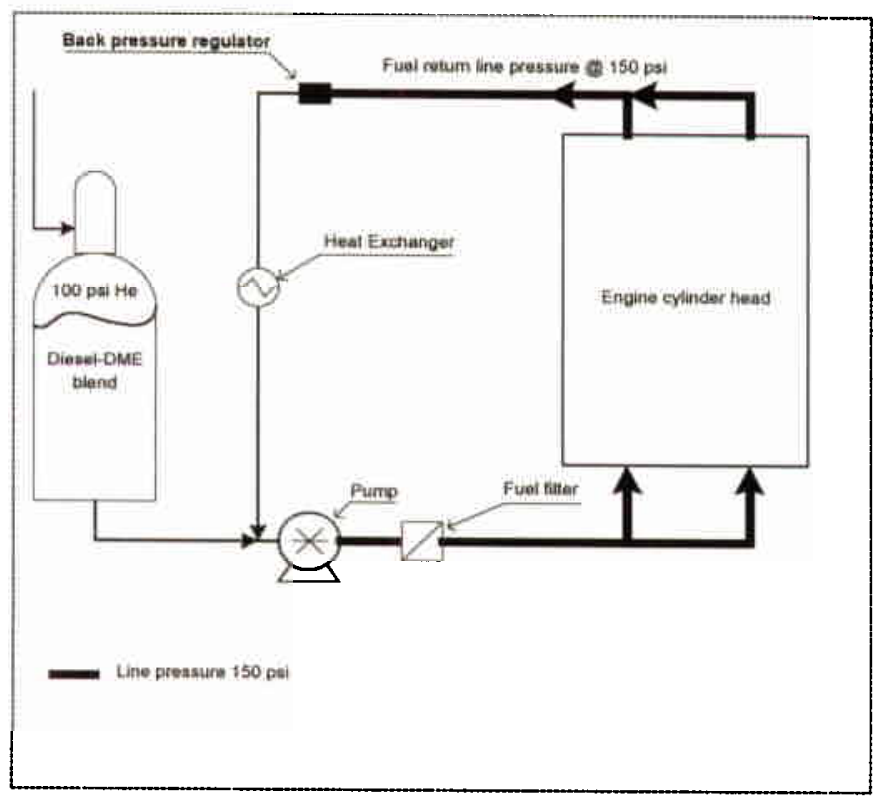

Figure 2. Dlagram of Pressurized Fuel System

From the previous studies on this same engine for the 2 wt.\% oxygen in diesel, the cooling capacity of the heat exchanger and fuel circuit was determined to be insufficient, based on the fuel temperatures recorded, as well as, observed engine instabilities [37]. Therefore, the system shown in Figure 2 represents the modifications made, which included the addition of a second fuel coil in the cooled bath, and a larger chiller unit for cooling the bath. Additionally, the system was pressurized to $150 \mathrm{psi}$, which then increases the allowable fuel temperature before the DME becomes vapor.

\section{RESULTS AND DISCUSSION}

In this next section, detailed results are provided for the effect of the additive on emissions. Fuel property data is available in Table 3 so that comparisons of the combustion data can be analyzed. Through an uncertainty analysis, based on methods described by Moffat, error bars showing the $95 \%$ confidence intervals are presented in each figure [38].

PARTICULATES- As noted previously in the discussion, oxygenates traditionally reduce particulate emissions. The data from this testing indicates that this general trend is for all modes the engine was able to operate, as shown in Figure 3. Using the AVL 8-mode test, the net particulate emission reductions for each mode are found in Table 4. Because the engine was not able to be run for modes 4 and 8 for each additive, the data was presented in a mode by mode comparison. For most modes, shown in Figure 3, particulate reductions were observed on a particulate matter vs. fuel consumed basis. As the engine load is increased, the particulate emission is lowered, except for mode 4. This is true for the low as well as the high engine speeds. The trends follow what would be expected from prior work on oxygenated fuels. Mode 4 operates the engine near the peak torque, and the overall emissions change, possibly due to a change in the injection timing.

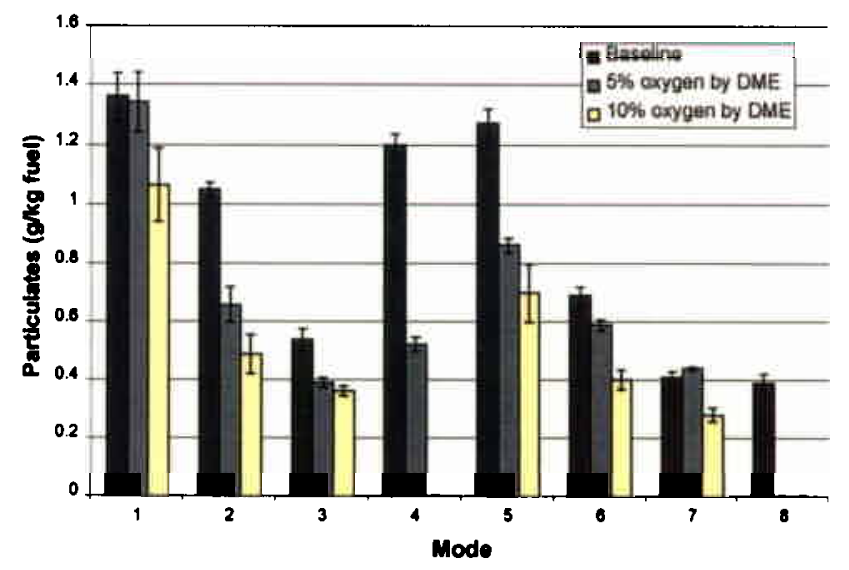

Figure 3. Particulate Matter Results per unit fuel consumed, g/kg fuel

As has been shown in previous work, this particulate reduction is due to a reduction in the soot portion of the 
emission, which would result in a percentage increase in the soluble organic faction (SOF) portion [6]. This has also been confirmed more recently by Sidhu and coworkers [39], with DME giving the highest SOF.

OXIDES OF NITROGEN $\left(\right.$ NO $\left._{x}\right)$-Table 4 reports the brake specific $\mathrm{NO}_{x}\left(\mathrm{BSNO}_{x}\right)$ emissions. Figure 4 shows that at lower loads $\mathrm{NO}_{x}$ decreases. At higher loads, $\mathrm{NO}_{\mathrm{x}}$ increases. The oxygenated additive leads to reduced $\mathrm{NO}_{x}$ at the lower load conditions, possibly due to the injection timing of the engine. The $\mathrm{NO}_{x}$ emission decreases for the $5 \mathrm{wt}$. \% oxygen, and then begins to increase with additional oxygen content, as shown in modes 1 and 2. The Hydraulically actuated Electronically controlled Unit Injector (HEUI) use a split shot injection at the lower engine speeds, which may be providing better mixing to the fuel and air, and thus reducing $\mathrm{NO}_{\mathrm{x}}$. At higher engine speeds, $\mathrm{NO}_{\mathrm{x}}$ is lower, and $\mathrm{NO}_{x}$ increases as load increases. There are conflicting reports in the literature as to whether oxygenates increase or decrease $\mathrm{NO}_{x}$ emissions $[3,5,6,12,16]$. The data from this engine, however, shows a reduction in $\mathrm{NO}_{x}$ emissions on a brake specific basis, for most modes. Choi and Reitz [5] observed that there is a small penalty on the $\mathrm{NO}_{\mathrm{x}}$ emissions when using a split injection strategy (two fuel pulses) with an oxygenated fuel, which could be affecting the results for modes 1 and 2 for this particular engine. Because the unique multiple fuel injection strategy of the Navistar T444E is especially predominant at lower speeds, the $\mathrm{NO}_{x}$ reduction could occur due to better improved mixing effect in the cylinder during the combustion event. 
Table 4. AVL 8-mode Emissions Results per mode, Brake Specific Basis

a.

\begin{tabular}{|l|l|l|l|}
\hline $\begin{array}{l}\text { Particulate } \\
\text { Emissions } \\
\text { Per Mode }\end{array}$ & $\begin{array}{l}\text { Baseline } \\
\text { Diesel } \\
\text { (g/bhp-hr) }\end{array}$ & $\begin{array}{l}\text { 5wt. \% } \\
\text { oxygen via } \\
\text { DME } \\
\text { (g/bhp-hr) }\end{array}$ & $\begin{array}{l}\text { 10wt. \% } \\
\text { oxygen via } \\
\text { DME } \\
\text { (g/bhp-hr) }\end{array}$ \\
\hline 1 & 3.36 & 3.44 & 2.87 \\
\hline 2 & .224 & .149 & .118 \\
\hline 3 & .091 & .069 & .082 \\
\hline 4 & .209 & .095 & NA \\
\hline 5 & .339 & .255 & .214 \\
\hline 6 & .137 & .128 & .092 \\
\hline 7 & .078 & .086 & .057 \\
\hline 8 & .068 & NA & NA \\
\hline
\end{tabular}

c.

\begin{tabular}{|l|l|l|l|}
\hline $\begin{array}{l}\text { CO } \\
\text { Per Mode }\end{array}$ & $\begin{array}{l}\text { Baseline } \\
\text { Diesel } \\
\text { (g/bhp-hr) }\end{array}$ & $\begin{array}{l}\text { 5wt. \% } \\
\text { oxygen via } \\
\text { DME } \\
\text { (g/bhp-hr) }\end{array}$ & $\begin{array}{l}\text { 10wt. \% } \\
\text { oxygen via } \\
\text { DME } \\
\text { (g/bhp-hr) }\end{array}$ \\
\hline 1 & 40.0 & 51.8 & 75.93 \\
\hline 2 & 1.60 & 1.97 & 2.75 \\
\hline 3 & .560 & .689 & .671 \\
\hline 4 & 8.12 & 7.63 & NA \\
\hline 5 & 2.33 & 4.16 & 6.59 \\
\hline 6 & .913 & 1.344 & 2.10 \\
\hline 7 & .691 & .875 & .916 \\
\hline 8 & .493 & NA & NA \\
\hline
\end{tabular}

b.

\begin{tabular}{|l|l|l|l|}
\hline $\begin{array}{l}\text { NOx } \\
\text { Per Mode }\end{array}$ & $\begin{array}{l}\text { Baseline } \\
\text { Diesel } \\
\text { (g/bhp-hr) }\end{array}$ & $\begin{array}{l}\text { 5wt. \% } \\
\text { oxygen via } \\
\text { DME } \\
\text { (g/bhp-hr) }\end{array}$ & $\begin{array}{l}\text { 10wt. \% } \\
\text { oxygen via } \\
\text { DME } \\
\text { (g/bhp-hr) }\end{array}$ \\
\hline 1 & 43.91 & 24.74 & 36.54 \\
\hline 2 & 3.31 & 3.21 & 4.14 \\
\hline 3 & 3.52 & 3.85 & 4.80 \\
\hline 4 & 3.35 & 4.01 & NA \\
\hline 5 & 3.18 & 2.36 & 2.40 \\
\hline 6 & 2.44 & 2.05 & 2.11 \\
\hline 7 & 2.37 & 2.67 & 2.99 \\
\hline 8 & 3.42 & NA & NA \\
\hline
\end{tabular}

d.

\begin{tabular}{|l|l|l|l|}
\hline $\begin{array}{l}\text { Hydrocarbon } \\
\text { Per Mode }\end{array}$ & $\begin{array}{l}\text { Baseline } \\
\text { Diesel } \\
\text { (g/bhp-hr) }\end{array}$ & $\begin{array}{l}\text { 5wt. \% } \\
\text { oxygen via } \\
\text { DME } \\
\text { (g/bhp-hr) }\end{array}$ & $\begin{array}{l}\text { lowt. \% } \\
\text { oxygen via } \\
\text { DME } \\
\text { (g/bhp-hr) }\end{array}$ \\
\hline 1 & 34.3 & 51.4 & 48.5 \\
\hline 2 & .707 & 1.78 & 1.54 \\
\hline 3 & .211 & .953 & 1.54 \\
\hline 4 & .137 & .561 & NA \\
\hline 5 & .549 & 3.07 & 3.18 \\
\hline 6 & .216 & 1.22 & 1.28 \\
\hline 7 & .127 & .777 & .430 \\
\hline 8 & .094 & NA & NA \\
\hline
\end{tabular}




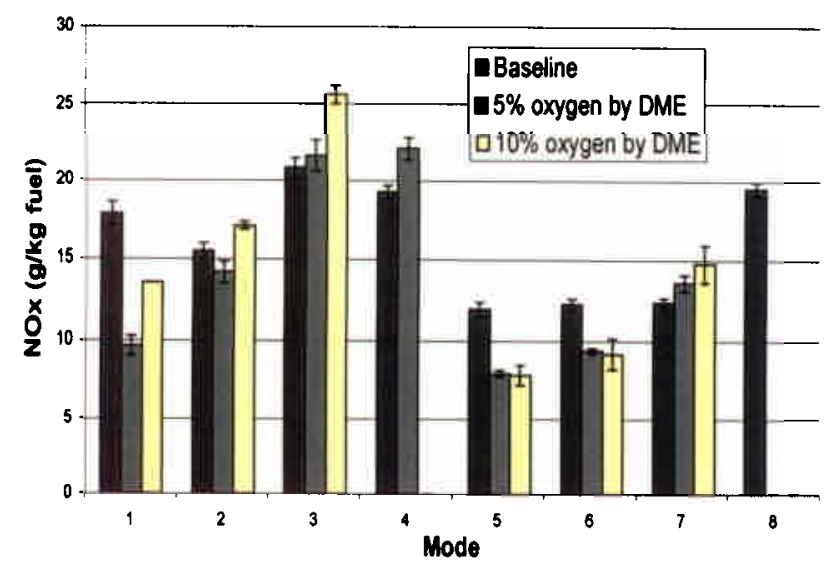

Figure 4. NOx Emission Results per unit fuel consumed, $\mathrm{g} / \mathrm{kg}$ fuel

Figure 5 presents the particulate matter vs. $\mathrm{NO}_{\mathrm{x}}$ tradeoff per mode. As can be seen for modes with lower loads, as particulates are reduced, $\mathrm{NO}_{x}$ is reduced. However, for modes 3, 4 and 7 , an increase in $\mathrm{NO}_{x}$ with decreasing particulates is observed. In some cases, the $\mathrm{PM} \mathrm{NO}_{\mathrm{x}}$ emissions point shifts toward the origin, which demonstrates that oxygen addition is a viable means of reducing diesel engine emissions. However, this is not true for all cases, and could possibly be due to changes in injection timing by the engine controls, and not necessarily a function of the changing fuel properties.

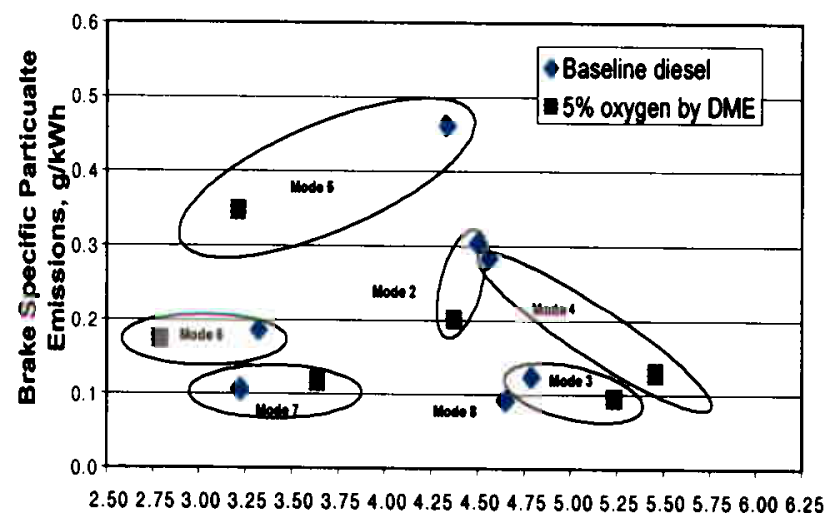

Brake Specific NOx Emissions,g/kWh

Figure 5. Brake-Specific Particulate Emission vs. NOx Emission Tradeoff

CARBON MONOXIDE (CO)- Table 4 reports the brake specific CO (BSCO) emissions. On a CO per unit of fuel basis, CO emissions increase as the wt. \% oxygen is increased, with a decreasing effect as the load increases. In general, $\mathrm{CO}$ decreases as load increases, as shown in Figure 6. This may again support the idea that during the low speed and low load conditions, $\mathrm{CO}$ formed during early reaction of the fuel is impeded from conversion to $\mathrm{CO}_{2}$. This was postulated by Litzinger and coworkers [12]. As explained by Glassman, the conversion of $\mathrm{CO}$ to $\mathrm{CO}_{2}$ would be a function of the size of the hydroxyl radical pool, which does not grow until most all the original fuel and hydrocarbons have been consumed [40]. Since the concentration of hydroxyl radicals is important in the rate of $\mathrm{CO}$ oxidation, the additional molecules of oxygen from DME may be playing a role in providing excess $\mathrm{CO}$ and $\mathrm{CO}_{2}$ which continue the creation of the hydroxyl radical pool. In addition, Flynn and coworkers show through kinetic simulations that the addition of the oxygen in the fuel leads to reduced amounts of soot precursors, and larger amounts of carbon leaving the fuel rich premixed combustion zone as CO [41].

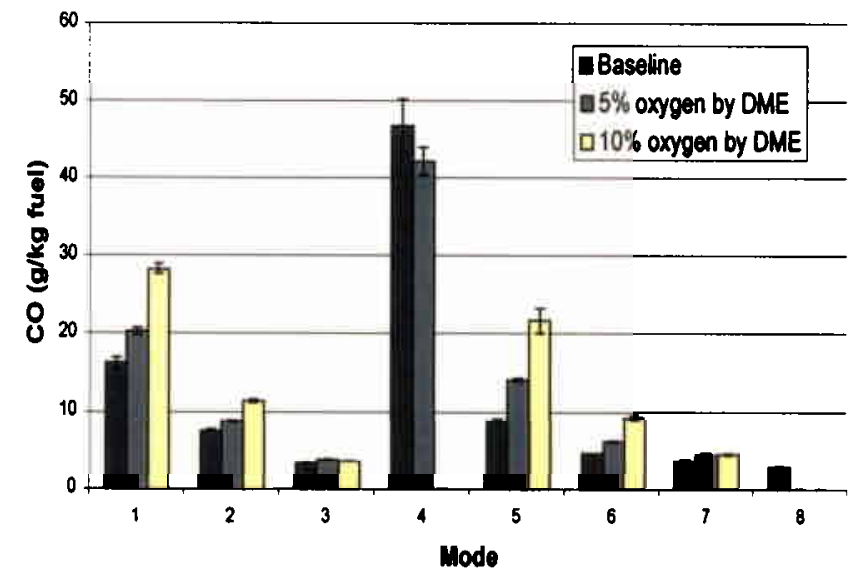

Figure 6. CO Emission Results per unit fuel consumed, $\mathrm{g} / \mathrm{kg}$ fuel

HC- The brake specific emissions for each mode are reported in Table 4. In general, the $\mathrm{HC}$ emissions decrease with higher engine loads, as the engine combustion efficiency increases. For all modes, HC emissions increase with oxygen addition, and decrease as engine load increases, as seen in Figure 7. For the lower engine speeds, as the oxygen addition increases, the $\mathrm{HC}$ emissions decrease. However, because very few data points are involved with this figure, it would be important to repeat the study. This data is inconsistent with what has been observed by some previous engine studies. 


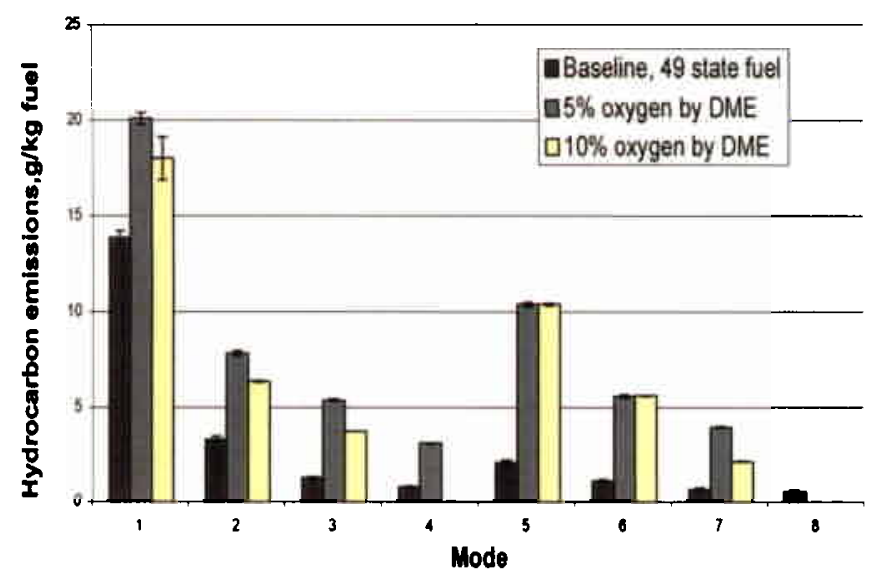

Figure 7. Hydrocarbon Emission Results per unit fuel consumed, $g / \mathbf{~ g g}$ fuel

FUEL CONSUMPTION- Figure 8 reports the brake specific fuel consumption (BSFC) for the DME addition. The general trend shows an increase in the amount of fuel required to maintain the same speed and load. This is due to the slightly lower calorific value of the fuel blend, as shown in the Fuel Properties of Table 3. However, when fuel consumption is calculated on an energy basis, the energy consumption results are not significantly different.

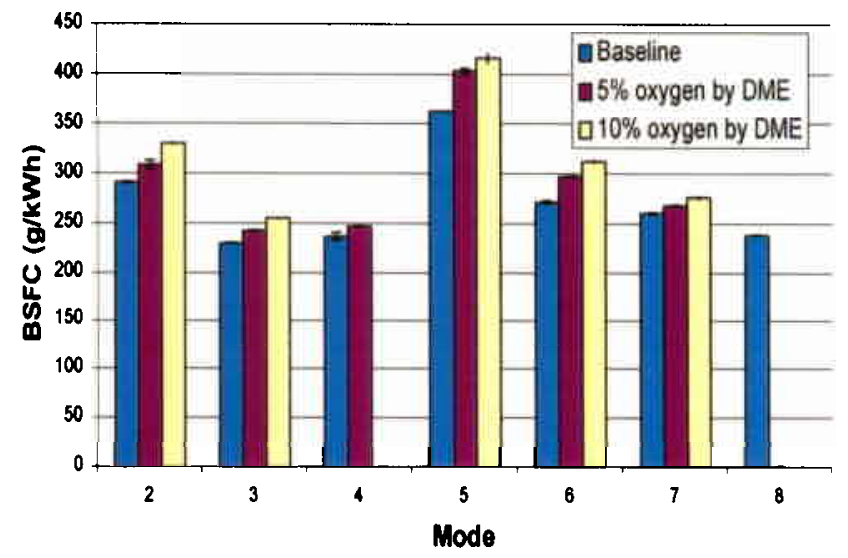

Figure 8. Brake Specific Fuel Consumption (BSFC)

\section{CONCLUSION}

On-going research continues in testing and reviewing the effects of oxygenates on the composition of emissions from diesel engines. The results in this paper lead to the following conclusions:
- DME has been shown to reduce particulate emissions from a DI diesel engine. Through the addition of oxygen contained within the hydrocarbon structure of the fuel, additional $\mathrm{CO}$ and $\mathrm{CO} 2$ are present in the combustion process. This prevents the formation of soot precursors, which reduces the formation of particulates.

- Higher amounts of CO have been observed for each mode. This can be explained by the presence of the fuel born oxygen creating a larger pool of $\mathrm{CO}$ and $\mathrm{CO}_{2}$, which aids in creating hydroxyl radicals, thus quenching the combustion process and leaving $\mathrm{CO}$ not oxidized.

- It has also been observed that along with a reduction in particulate emissions per mode, there is a small $\mathrm{NO}_{x}$ reduction for some modes. It is unclear what may be causing this, but several possible reasons are given. Multiple injections at lower loads and speeds may explain the reason for this data. Also, there may be some affect of the increased fueling required by the engine, as the fuel oxygen content changes. The net effect is some change in the ignition timing of the fuel, as a result of the engine control adjusting injection timings differently for each fuel.

\section{ACKNOWLEDGMENTS}

The authors wish to acknowledge the support of Air Products and Chemicals, Inc., the Pennsylvania Department of Environmental Protection and the National Energy Technology Laboratory of the U.S. Department of Energy. In particular, the authors wish to acknowledge the support and encouragement of John Winslow, Mike Nowak, and Jenny Tennant of NETL, Susan Summers of the PA-DEP and Barry Halper, Jo Ann Franks, and James Hansel of Air Products. The authors would also like to acknowledge Glen Chatfield of Optimum Power for providing the PtrAn software. The authors would like to acknowledge Navistar for their continued technical support of this project. In addition, the authors wish to acknowledge technical support from W. Swain, S. Bhide, J. Szybist, Dr. L.I. Boehman, J. Stefanik and $\mathrm{H}$. Hess.

This paper was written with support of the U.S. Department of Energy under Contract No. DE-FG2999FT40161. The Government reserves for itself and others acting on its behalf a royalty-free, nonexclusive, irrevocable, worldwide license for Governmental purposes to publish, distribute, translate, duplicate, exhibit, and perform this copyrighted paper.

This material was prepared with the support of the Pennsylvania Department of Environmental Protection. 
Any opinions, findings, conclusions, or recommendations expressed herein are those of the author(s) and do not necessarily reflect the views of the DEP.

\section{REFERENCES}

1. Karim, G.A., "Combustion in Gas Fueled Compression-Ignition Engines", ICE Paper No. 2000-ICE-299, Vol.35-1, ASME ICE Fall Technical Conference (2000).

2. Neeft, J.P.A., Makkee, M. and Moulijn, J.A. Fuel Proc. Tech., 47:1-69 (1996).

3. McCormick, R.L., Ross, J.D. and Grabowski, M.S., Environ. Sci. Tech., 31:1144-1150 (1997).

4. Grabowski, M.S. and McCormick, R.L. Prog. Energy and Combust. Sci. 24:125-164 (1998).

5. Choi, C.Y. and Reitz, R.D. Fuel, 78:1303-1317 (1999).

6. Liotta, F.J, and Montalvo, D.M., Society of Automotive Engineers Technical Paper No. 932734, Society of Automotive Engineers, Warrendale, PA (1993).

7. Ullman, T.L., Spreen, K.B. and Mason, R.L., Society of Automotive Engineers Technical Paper No. 941020, Society of Automotive Engineers, Warrendale, PA (1994).

8. Spreen, K.B., Ullman, T.L. and Mason, R.L. Society of Automotive Engineers Technical Paper No. 950250, Society of Automotive Engineers, Warrendale, PA (1995).

9. Tsurutani, K., Takei, Y., Fujimoto, Y., Matsudaira, J. and Kumamoto, M., Society of Automotive Engineers Technical Paper No. 952349, Society of Automotive Engineers, Warrendale, PA (1995).

10. Hess, H.S., Roan, M.A., Bhalla, S., Butnark, S., Zarnescu, V., Boehman, A.L., Tijm, P.J.A. and Waller, F.J., ACS Preprints, Division of Petroleum Chemistry, 43(4):593-596 (1998).

11. Stoner, M. and Litzinger, T., Society of Automotive Engineers Technical Paper No. 1999-01-1475, Society of Automotive Engineers, Warrendale, PA (1999).

12. Litzinger, T., Stoner, M., Hess, H. and Boehman, A., Int. J. Engine Res., accepted for publication (2000).

13. Beatrice, C., Bertoli, C., D'Alessio, J., Del Giacomo, N., Lazzaro, M. and Massoli, P. Comb. Sci. and Tech., 120:335-355 (1996).

14. Bertoli, C., Del Giacomo, N. and Beatrice, C., Society of Automotive Engineers Technical Paper No. 972972, Society of Automotive Engineers, Warrendale, PA (1997).

15. Beatrice, C., Bertoli, C. and Del Giacomo, N. Comb. Sci. Tech., 137:31-50 (1998).

16. Beatrice, C., Bertoli, C., Del Giacomo, N. and Migliaccio, M.na., Society of Automotive Engineers Technical Paper No. 1999-01-3595, Society of Automotive Engineers, Warrendale, PA (1999).
17. Miyamoto, N., Ogawa, H., Nurun, N.M., Obata, K. and Arima, T., Society of Automotive Engineers Technical Paper No. 980506, Society of Automotive Engineers, Warrendale, PA (1998).

18. Nabi, M.N., Minami, M., Ogawa, H. and Miyamoto, N., Society of Automotive Engineers Technical Paper No. 2000-01-0231, Society of Automotive Engineers, Warrendale, PA (2000).

19. Edgar, B.L., Dibble, R.W. and Naegeli, D.W., Society of Automotive Engineers Technical Paper No. 971677, Society of Automotive Engineers, Warrendale, PA (1997).

20. Murayama, T., Zheng, M., Chikahisa, T., Oh, Y.-T., Fujiwara, Y., Tosaka, S., Yamashita, M. and Yoshitake., H., Society of Automotive Engineers Technical Paper No. 952518, Society of Automotive Engineers, Warrendale, PA (1995).

21. Rubino, L. and Thompson, M.J., Society of Automotive Engineers Technical Paper No. 199901-3589, Society of Automotive Engineers, Warrendale, PA (1999).

22. Hansen, J., etal. Society of Automotive Engineers Technical Paper No. 950063, Society of Automotive Engineers, Warrendale, PA (1995).

23. Ofner, H., et al., Society of Automotive Engineers Technical Paper No. 981158, Society of Automotive Engineers, Warrrendale, PA (1998).

24. Sivebeck,I, et.al., Society of Automotive Engineers Technical Paper No. 2001-01-2013, Society of Automotive Engineers, Warrendale, PA (2001).

25. Sorenson, S.C., and Mikkelsen, S., Society of Automotive Engineers Technical Paper No. 950064, Society of Automotive Engineers, Wartrendale, PA (1995).

26. Mikkelsen, S.C., et al., Application of Powertrain and Fuel Technologies to Meet Emissions Standards , IMechE, p.289, (1996).

27. Christensen, R., et al., Society of Automotive Engineers Technical Paper No. 971665, Society of Automotive Engineers, Warrendale, PA (1997).

28. Kajitani, S., et al., Society of Automotive Engineers Technical Paper No. 972973, Society of Automotive Engineers, Warrendale, PA (1997).

29. Hupperich, P., et al., ASME Technical Paper No. 97ICE-65, ASME 1997 Fall Technical Conference, ICE-Vol. 29-3, (1997).

30. Ikeda, M., et al., Society of Automotive Engineers Technical Paper No. 2000-01-2006, Society of Automotive Engineers, Warrendale, PA (2000).

31. Hallgren B., and Heywood, J., Society of Automotive Engineers Technical Paper No. 2001-01-0648, Society of Automotive Engineers, Warrendale, PA (2001).

32. Mueller, M., Yetter, R., and Dryer, F., TwentySeventh Symposium (International) on Combustion, 177-184 (1998). 
33. Dagaut, P., Daly, C., Simmie, J., and Cathonnet, M., Twenty-Seventh Symposium (International) on Combustion, 361-369 (1998).

34. Amano T., and Dryer, F., Twenty-Seventh Symposium (International) on Combustion, 397-404 (1998).

35. Fleisch,T., McCarthy, C., Basu, A., Udovich, C., Charbonneau, P., Slodowske, W., Mikkelsen, S., McCandless, J., Society of Automotive Engineers Technical Paper No. 950061, Society of Automotive Engineers, Warrendale, PA (1995).

36. Hess, H., Boehman, A., Tijm, P., and Waller, F.J., Society of Automotive Engineers Technical Paper No. FL-00-0566, Society of Automotive Engineers, Warrendale, PA. (2000).

37. Chapman, E., Bhide, S., and Boehman, A., Society of Automotive Engineers Technical Paper No. 200001-2887, Society of Automotive Engineers, Warrendale, PA (2000).

38. Moffat, R.J., Experimental Thermal and Fluid Science, 1:3-17 (1988).

39. Sidhu, S., et al., Chemopshere Vol. 42, pg. 681-690, (2001).

40. Glassman, I. Combustion, $2^{\text {nd }}$ edition, Oriando, FL: Academic Press, 1987.

41. Flynn, P.F.,et al., Society of Automotive Engineers Technical Paper No. 1999-01-0509, Society of Automotive Engineers, Warrendale, PA (1999).

42. Tijm, P.J.A., Waller, F.J., Toseland, B.A. and Peng, X.D., "Liquid Phase Di-Methyl Ether TM' A promising New Diesel Fuel", Energy Frontiers International Conference, Alaska (1997).

43. Bhide, S. Boehman, A., and Perez, J., "Viscosity of DME-Diesel fuel blends", to be presented at American Chemical Society, National Meeting, Chicago, IL, August 2001. 